\title{
Avoidance Behaviors of Exporters and Importers: Evidence from the U.S.-China Trade Data Discrepancy*
}

\author{
Michael J. Ferrantino \\ U.S. International Trade Commission \\ Michael.Ferrantino@usitc.gov \\ Xuepeng Liu \\ Kennesaw State University \\ xliu6@kennesaw.edu \\ Zhi Wang \\ U.S. International Trade Commission \\ Zhi.Wang@usitc.gov
}

\begin{abstract}
March 2010
ABSTRACT

Since the late 1990s, reported U.S. imports from China and Hong Kong have regularly and increasingly exceeded reported exports of China and Hong Kong to the United States. This discrepancy, which is not caused by re-exporting through Hong Kong, varies by product categories, and in some cases takes the opposite sign. In this paper, we focus on China's direct exports to the United States. Using a model that allows for simultaneous misreporting to two authorities, we find strong statistical evidence of under-reporting exports at the Chinese border to avoid paying value-added tax (VAT). We also provide evidence of tariff evasion at the U.S. border, in particular for related-party transactions, and indirect evidence of transfer pricing and evasion of Chinese capital controls.
\end{abstract}

Key words: trade data discrepancy, tax evasion, export VAT rebates, transfer pricing

\section{JEL Classification Numbers: H26, F1}

*The views expressed in this paper are solely those of the authors, and are not meant to represent in any way the views of the U.S. International Trade Commission or any of its Commissioners. The authors thank Guohua Huang of China Customs; Dong Liu of the Chinese Embassy in Washington, DC; and Glenn Barresse, Timothy Baxter, and David Dickerson of the U.S. Census Bureau with assistance on data; Aaron Hedlund, Kendall Dollive, and Elaine Aguasvivas for research assistance; and participants at presentations at Georgia State University, Georgia Institute of Technology, George Washington University, the Southern Economic Association, and the Italian Statistical Society for helpful comments. Xuepeng Liu thanks the Coles College of Business at Kennesaw State University for partial financial support. Any remaining errors or omissions remain the responsibility of the authors. 


\section{Introduction}

The growing trade relationship between the United States and China has drawn increasing attention. The increasing U.S. trade deficit with China is frequently viewed with alarm in U.S. policy circles, and is often referenced in the context of calls for changes in China's exchange rate policy (e.g. Palley, 2005; Bipartisan China Currency Action Coalition, 2007). It has been noted, however, that China's reported exports to the United States are routinely smaller than U.S. reported imports from China. ${ }^{1}$ Economists have traditionally sought to explain the discrepancy by the large share of China's trade re-exported through the customs territory of Hong Kong. Goods which are exported from China to Hong Kong, and then to the United States, are likely to be counted in U.S. data as imports from China but in China's data as exports to Hong Kong. Hong Kong's trade statistics include both domestic (Hong Kong origin) exports to the United States and re-exports of goods of Chinese origin to the United States. When the sum of exports from China and Hong Kong to the United States is compared with U.S. imports from China and Hong Kong together, most of the discrepancy disappears on data from 1979-1993 (Figure 1a), even before shipping margins are accounted for. Re-exportation through Hong Kong has been accepted by many researchers as a sufficient explanation for the data problem (see, e.g., West, 1995; Fung and Lau, 1998, 2004; Feenstra, Hai, Woo, and Yao, 1999; Fung, Lao, and Xiong, 2006).

However, as the role of Hong Kong as an entrepôt for China-U.S. trade has decreased, it has become increasingly apparent that a sizable amount of the discrepancy has other origins. Ferrantino and Wang (2008) noticed that even when the role of Hong Kong is very carefully accounted for, taking into account transport costs and the difference in geographical definitions, U.S. reported imports from China and Hong Kong have grown persistently larger than the sum of China's and Hong Kong's reported exports to the United States (Figure 1b). The difference in 2007 was nearly $\$ 52$ billion, declining slightly in 2008 to 49 billion. The 2007 difference amounts to about 16 percent of the reported U.S. number, or about 18 percent of the total figure reported by China and Hong Kong together. This discrepancy has grown at the same time that the role of Hong Kong as a "middleman" between China and the United States has shrunk. Expressed as a share of U.S. reported imports from China, the share of Hong Kong re-exports of

\footnotetext{
${ }^{1}$ Discrepancies between exporters' and importers' trade data are endemic globally, and not peculiar to the U.S.China relationship (see, e.g., Tsigas, Hertel and Binkley, 1992; Gehlhar, 1996).
} 
goods of Chinese origin has declined from about 61 percent in 1995 to less than 12 percent in 2008 (Figure 2a). Obviously, this newly emerged pattern of discrepancy in the data cannot be explained simply by a failure to account for re-exporting through Hong Kong. One ought to look elsewhere for a primary explanation. By carefully comparing detailed customs records from China, Hong, Kong, and the United States, Ferrantino and Wang (2008) shows that direct exports from Chinese ports and Chinese exports through third countries account for most of the statistical discrepancy relative to trade flows involve Hong Kong (Figure 2b). The discrepancy on direct Chinese exports to the United States (neither re-exports nor transshipments) increased from approximately $\$ 1.7$ billion in 1995 to $\$ 39$ billion in 2007 and consistently accounts for more than half of the total discrepancy since 1998. This suggests that traders may be systematically misstating the value of shipments, either understating them to China's customs authorities, overstating them to U.S. authorities, or both. ${ }^{2}$

In this paper, we investigate a variety of patterns of tax avoidance, tariff evasion, and avoidance of capital controls that could give rise to such discrepancies. Depending on the structure of incentives, these types of avoidance behaviors could lead to the opposite result, i.e. over-reporting of data to Chinese authorities or under-reporting of data to U.S. authorities. In particular, the case of tariff evasion has been studied by several authors (e.g., Fisman and Wei, 2004; Fisman, Moustakerski, and Wei, 2008; Javorcik and Narciso, 2008; Mishra, Subramanian, and Topalova, 2008). Since tariff evasion involves under-reporting of values to the importing country's authority, it cannot be the primary explanation for the U.S.-China trade data discrepancy. Nonetheless, tariff avoidance may still take place. There are more than $40 \%$ of product categories at 6-digit HS level for which the discrepancy actually takes the opposite sign, with reported Chinese data being larger. At least some of these may be due to evasion of U.S. tariffs.

We first develop a partial equilibrium model for misreporting incentives in international trade. The model allows us to highlight various possible explanations of the observed trade statistics discrepancies in a unified economic framework. We then use a unique dataset which merges finely disaggregated trade data from China Customs and the U.S. Census during 20022008 to test the model and shed light on the type of trader behaviors which may give rise to the

\footnotetext{
${ }^{2}$ An official U.S-China statistical working group has noted that unit values for China's processed exports directly shipped to the United States are lower than those for the corresponding U.S. imports (U.S. Department of Commerce et al., 2009), suggesting that the difference may be due to purchases and re-sales by intermediary parties.
} 
observed discrepancy. We find strong statistical evidence for under-reporting of exports at Chinese border to avoid paying China's value-added tax (VAT). We also find indirect evidence of transfer pricing (i.e. over-reporting at the U.S. border to avoid higher U.S. corporate income tax for U.S. based multi-nationals) and avoidance of Chinese capital controls (i.e. moneylaundering). To explain the larger values reported by the U.S. for some products, we also provide evidence of tariff evasion at the U.S. border.

At present, the Chinese government uses frequent and product-specific changes in the VAT, as reflected in the rebate rate, for a wide variety of policy purposes, ranging from promoting high and new technology products to discouraging environmentally "dirty" goods to managing the general trade balance and specific trade frictions in products such as textiles and steel. It may be questioned a priori whether a single policy instrument can bear the weight of being addressed to so many objectives simultaneously. Our results imply that even if such a policy could work in an ideal case, i.e. by optimally differentiating the VAT rebate for different products, its effectiveness is at present being undermined by widespread avoidance of the VAT on the part of exporting firms.

The rest of the paper is organized as follows. Section 2 presents our misreporting incentive model and discusses the major economic incentives for firms to misreport export and import transactions in China-U.S. eastbound trade. Section 3 describes data and their sources as well as various proxy variables for misreporting incentives used in our analysis. Section 4 presents our econometric specifications and discusses major findings based on our estimation results. Section 5 concludes.

\section{Economic Incentives for Misreporting}

There are a number of incentives for firms to misstate the invoice price of an export-import transaction, such as tax avoidance, tariff evasion, transfer pricing, and avoidance of capital controls. These incentives can give rise to discrepancies in trade statistics because there are multiple authorities involved, and there may be an incentive to tell different things to authorities in different countries. The primary goal of our analysis is to understand why U.S. reported imports are systematically larger than the same exports as reported by China. We argue that avoidance of the Chinese VAT, avoidance of corporate income taxes in both countries, and avoidance of Chinese capital control are possible factors underlying either the under-reporting of 
exports at Chinese border or the over-reporting of imports at the U.S. border. In consistence with the literature on tariff evasion, as discussed above, we find some evidence for tariff evasion at the U.S. border. We also draw out some additional implications about firm behaviors from econometric analysis of the observed discrepancy. The discrepancy has narrowed since 2005. This is consistent with the possibility that incentives for avoiding Chinese capital controls, which previously favored unrecorded capital outflow from China, may now favor unrecorded capital inflow into China. Such a shift is consistent with actual and expected appreciation of the Chinese currency in the most recent period. The apparent greater degree of tariff evasion for related-party transactions may reflect provisions of customs valuation peculiar to the United States (the socalled "First Sale Rule").

\subsection{A simple model of misreporting incentives}

Our basic setup is straightforward and modifies analyses of the transfer pricing problem within multinational firms such as Swenson (2001) for U.S. imports and Bernard, Jensen and Schott (2006) for U.S. exports. These analyses have derived useful expressions for the optimal transfer price for a firm engaged in intra-firm trade, and liable for corporate income taxes in both countries and tariffs in the importing country. However, the analysis of discrepancies in trade data has particular features which bear emphasis. The incentives for misreporting trade values are not the same as those for transfer pricing, though they have many similarities. The relevant features include the following: First is the fact that different authorities receive different information. ${ }^{3}$ Second, a large share of U.S. imports from China involves unrelated parties. Thus, one would not expect transfer pricing to be involved in such transactions, but misreporting might well be. U.S. data show that only about 25 percent of U.S. imports from China consist of relatedparty trade. Third, Chinese exporters are subject to both a corporate income tax and a valueadded tax (VAT). The incidence of these taxes varies substantially across firm types and product categories.

Our misreporting model outlined below modifies Swenson (2001) in several ways to incorporate the stylized fact discussed above. The most important of these is that there are two

\footnotetext{
3 This is recognized by Swenson (2001) who assumes separate penalties assigned by the home and foreign authorities, but still derives a single transfer price which presumably is reported to both sets of authorities. Bernard, Jensen and Schott (2006) use a single penalty function, and thus implicitly assume that the same transfer price is reported to both sets of authorities. Empirical evidence that U.S. export prices are sensitive to tariffs and corporate income tax rates in the importing country provides some evidence that this may not be unreasonable.
} 
statistical agencies, one in the exporting country (i.e. China Customs) and the other in the importing country (i.e. U.S. Customs), and the firm has a choice as to what value of trade transactions to report to each country. By contrast, in a standard transfer pricing model there is one transfer price, which differs from the comparable arms' length price, and by assumption is reported identically to both countries' authorities. The model also adds additional policies in the exporting country: there is a VAT and a corporate profits tax, and there are capital controls both on money leaving and entering the exporting country. Both the VAT and capital controls provide additional incentives for misreporting to the exporting countries' authorities.

The consequence of replacing one transfer pricing decision with two misreporting decisions is to effectively de-link the incentives pertaining to Chinese conditions and U.S. conditions. This, in turn, implies that the misreporting behavior of two arms' length traders is identical to that of an integrated multinational firm. Misreporting is thus a more general phenomenon than transfer pricing, which may contribute to misreporting but is usually conceived of as an actual transfer of resources between the exporting and the importing countries to avoid taxes and tariffs. The standard transfer pricing model can be derived from our model by assuming that the same (misreported) value is reported to both countries' authorities, under a prohibitively high penalty for deviation. We relax this assumption because the large observed discrepancies in the data is consistent with a world in which firms do not place a high weight on the probability of being penalized simply because data reported to the exporting and importing countries' authorities are inconsistent.

We use the subscripts $\mathrm{x}$ and ${ }_{\mathrm{M}}$ to define information pertaining to the exporting country (China) and the importing country (United States), respectively. Define the deviations in prices reported to the exporters' customs authority and importers' customs authority, respectively, as

$$
\delta_{X}=P_{X}-P \text { and } \delta_{M}=P_{M}-P
$$

where $P$ represents the true price of the traded products. Let $Q$ represent the quantity of goods traded, $\tau_{X}$ and $\tau_{M}$ the corporate income tax rates in the exporting and importing country, TAR the tariff rate in the importing country, and $\theta$ the VAT rate in the exporting country. Let $\rho_{X}$ and $\rho_{M}$ represent the basic value of economic return (profit) to the exporter and the importer, in the

\footnotetext{
${ }^{4}$ Please note that our theoretical model is based on misreporting price or unit value. In reality, traders may misreport either price or quantity or both. In our empirical analysis, we will define the statistical discrepancy in trade value.
} 
absence of any avoidance or evasion behavior. The value-added is $(\rho+w)$, where $w$ represents the wage bill.

We assume the presence of capital controls in the exporting country only, on both the unlicensed import and export of capital. The shadow price of being able to avoid the capital control in either direction is expressed by $\lambda$, and is treated as exogenous but possibly varying across time and types of firms. Since incentives may change over time, sometimes unlicensed import of capital is profitable while at other times unlicensed export of capital is profitable. When incentives are such as to encourage net unrecorded capital inflow into the exporting country, $\lambda>0$, and when they are such as to encourage net unrecorded capital outflow, $\lambda<0$. Thus, the incentives for misreporting of trade due to capital controls can be added to the incentives due to tax and tariff evasion. In the absence of other incentives for misreporting, unrecorded capital inflow would be implemented by setting $\lambda>0$, justifying receipt of funds in excess of those needed to pay for exports, and unrecorded capital outflow would be implemented by setting $\lambda<0$, and leaving the difference in an account in the importing country. ${ }^{5}$ The value of $\lambda$ may change over time, according to changes in policy or speculation against anticipated exchange rate changes, and may also vary across different types of firms as some of them may face tighter capital controls or are more sophisticated in evading them.

The trader's cost function is augmented with a penalty function which represents the costs of being detected in misreporting the value of either exports or imports. Following Swenson (2001), we assume that the cost of detection is proportional to the volume of imports but quadratically increasing in the proportionate amount of the deviation. Following the implicit assumption of Bernard, Jensen, and Schott (2006), we assume that the penalty is added directly to the costs incurred by traders and is not tax-deductible (e.g. there may be jail time or other non-monetary costs incurred as part of the penalty). The variables $a_{X}$ and $a_{M}$, both assumed positive, represent the level of penalty (intensity of enforcement) in the exporting and importing country respectively. The total penalty increases quadratically in the amount of the deviation and linearly in the intensity of enforcement. $a_{X}$ and $a_{M}$ may vary in their intensity across time and firm types.

\footnotetext{
${ }^{5}$ The key here is that, in the absence of other incentives for misreporting, $\lambda$ always has the same sign as $\delta_{X}$, which guarantees that $\lambda * \delta_{X}$ enters the objective function as a positive term.
} 
Both the exporter and the importer minimize the costs of taxes, tariffs, and enforcement penalties, adjusted in the exporter's case for the net benefits of avoiding capital controls. Thus, the exporter's cost function is

$$
\min _{\delta_{X}} C_{X}=\theta\left(\rho_{X}+w+\delta_{X} Q\right)+\tau_{X}\left(\rho_{X}+\delta_{X} Q\right)+\frac{a_{X}}{2}\left(\frac{\delta_{X}}{P}\right)^{2} P Q-\lambda \delta_{X} Q
$$

while the importer's cost function is

$$
\min _{\delta_{\mathrm{M}}} C_{M}=\tau_{M}\left[\rho_{M}-\delta_{M} Q-T A R\left(P+\delta_{M}\right) Q\right]+T A R\left(P+\delta_{M}\right) Q+\frac{a_{M}}{2}\left(\frac{\delta_{M}}{P}\right)^{2} P Q
$$

It is evident that if the exporter and importer are part of the same firm, then the cost function for the combined firm takes the form $C_{X}\left(\delta_{X}\right)+C_{M}\left(\delta_{M}\right)$, which is separable in its arguments. Thus, there is no per se reason for the parties in an arms' length transaction to behave differently from the parties in an intra firm transaction with respect to misreporting. However, intra-firm transaction may facilitate misreporting through transfer pricing.

Optimization of the exporter's problem yields expressions for the reporting deviation and the reported price as

$$
\delta_{X}=\frac{\left(\lambda-\theta-\tau_{X}\right)}{a_{X}} P \text { and } P_{X}=\left(1+\frac{\left(\lambda-\theta-\tau_{X}\right)}{a_{X}}\right) P
$$

while optimization of the importers' problem yields the corresponding expressions

$$
\delta_{M}=\frac{\tau_{M}-T A R\left(1-\tau_{M}\right)}{a_{M}} P \text { and } P_{M}=\left(1+\frac{\tau_{M}-T A R\left(1-\tau_{M}\right)}{a_{M}}\right) P
$$

Therefore the percentage difference in observed reporting prices can be written as

$$
\text { Discrepancy }=\frac{\delta_{M}-\delta_{X}}{P}=\frac{P_{M}-P_{X}}{P}=\frac{\tau_{M}-T A R\left(1-\tau_{M}\right)}{a_{M}}-\frac{\left(\lambda-\theta-\tau_{X}\right)}{a_{X}}
$$

The economic interpretations of equations (4), (5) and (6), and their implications for econometric analysis of the observed discrepancy, are as follows:

For the exporting country, underreporting implies $\delta_{X}<0$. According to equation (4), underreporting is consistent with positive rates of corporate income tax and VAT $\left(\tau_{X}>0, \theta>0\right)$ and with $\lambda<0$, i.e. a situation in which capital controls work in such a way as to favor net capital outflow. The amount of underreporting is positively associated with the effective tax rates ( $\tau_{X}$ and $\theta$ ) and with the degree to which the control on outbound capital is binding $(\lambda)$. Over- 
reporting can take place if $\lambda>\left(\tau_{X}+\theta\right)$, i.e. when the incentives caused by evasion of capital control favor unrecorded capital inflow, and are sufficiently strong to outweigh the incentives caused by tax evasion. In the case of over-reporting by the exporter, the degree of over-reporting is positively associated with the intensity of capital controls and negatively associated with effective tax rates.

The analysis of misreporting by the importer is simpler since we assume no capital controls. Over-reporting implies $\delta_{M}>0$, while underreporting implies $\delta_{M}<0$. According to equation (5), the sign of $\delta_{M}$ is determined by the sign of the numerator, $\left[\tau_{M}-T A R\left(1-\tau_{M}\right)\right]$. A sufficient condition for over-reporting is $\tau_{M}>\operatorname{TAR}\left(1-\tau_{M}\right)$. Underreporting to the importer is only observed when tariff rate after tax deduction is larger than the effective tax rate $\tau_{M}$.

The observed reporting gap as defined in equation (6) is negatively associated with importing countries' tariff $(T A R)$, but positively associated with exporting country's net VAT tax rate $\theta$ and the corporate income tax rate in both the importing and exporting countries $\left(\tau_{M}\right.$ and $\left.\tau_{X}\right){ }^{6}$ The misreporting in absolute value on each side is negatively associated to the corresponding degree of enforcement ( $a_{M}$ and $a_{X}$ ). Using (6), the partial effects of Chinese VAT rates and U.S. tariffs on the observed discrepancy are functions of the enforcement intensity ( $a_{X}$ and $\left.a_{M}\right)$ :

$$
\frac{\partial \text { Discrepancy }}{\partial \theta}=\frac{1}{a_{X}} \text { and } \frac{\partial \text { Discrepancy }}{\partial T A R}=\frac{\tau_{M}-1}{a_{M}}
$$

Thus, high tariffs and VAT rates induce smaller discrepancies when enforcement levels are higher. We do not observe enforcement directly. However, we do observe differences in Chinese firm types, trade regimes, and the related party share in U.S. imports. We introduce these variables into our analysis, motivating their inclusion by the possibility that different types of transactions may be subject to different degrees of enforcement, as well as other unobserved differences in incentives for misreporting. We expect that domestic firms and normal exporters are more likely to under-report exports at Chinese border to evade VAT compared to foreign-

\footnotetext{
${ }^{6}$ When the choice variable is a single transfer price rather than two misreporting margins, the standard result is that a high transfer price is associated with high taxes in the importing country but low taxes in the exporting country. Our misreporting model, however, predicts that the size of the discrepancy is positively correlated with tax levels in both the exporting and the importing countries. This does not mean that the standard result is invalid. For example, multinationals may in fact choose to report a single optimal transfer price to both parties to shift profit from high income tax country to low income tax country, and avoid the cost of keeping separate accounting book for the same transaction. The standard transfer pricing model can be considered a special case of the misreporting model, applying to related party trade. The incentives implied by our misreporting model apply to all trade.
} 
invested enterprises and processing exporters, since the former set of firms are more deeply embedded in local institutions and possibly more able to take advantage of loopholes. There are a variety of reasons why related-party imports may face different incentives than arms' length imports in addition to those captured by the transfer pricing model; we discuss one of these, the so-called "First Sale Rule" below. In our regression analysis, we consider these possibilities by including interaction terms between taxes and these institutional variables.

The sign of the observed discrepancies is complicated by the presence of capital control in the exporting country. When importers' data larger than exporters' data, such as the case of China-U.S. eastbound trade, $\left(P_{M}-P_{X}>0\right.$ and $\left.\delta_{M}-\delta_{X}>0\right)$, the size of the observed gap will be larger when incentives favor unrecorded capital outflow from China, and will be smaller when incentives favor unrecorded capital inflow.

In order to use the general model developed in this section as a guide for empirical analysis, we need to find proper proxies to represent the various kinds of misreporting incentives specified. To do this, and to aid in the interpretation of the results, it is important to understand in more detail how the relevant features of taxation and capital control work, as well as certain institutional features of Chinese exports. These are discussed in the next three sub-sections.

\subsection{Incentives for misreporting at the Chinese border}

One of the key incentives behind the under-reporting of exports at Chinese border is export VAT avoidance. China's tax revenue relies primarily on VAT, which accounted for between 36 and 50 percent of China's government revenue in $2006 .^{7}$ China's VAT has several peculiar features distinguishing it from the VAT used in other countries. China's VAT is both destination-based (all goods sold in the country are taxed; the VAT is rebated on exports of domestically-produced goods) and production-based (no deduction is allowed for capital goods purchased during the current period). ${ }^{8}$ The destination basis of the VAT creates a difference between the tax treatment of domestic sales and trade. Moreover, imports are usually duty-free if they are used for producing exports. The practice of export tax rebates is widespread, and is

\footnotetext{
${ }^{7}$ China Statistical Yearbook 2008 and authors' calculations. The range is due to the category "Consumption Tax and Value-Added Tax on Imports," not broken out separately and accounting for 14 percent of revenues. The category "Value-Added Tax," accounting for 36 percent of revenues, likely refers to VAT on Chinese domestic production.

${ }^{8}$ See U.S. International Trade Commission (1998) for a contrast of the destination basis with the origin basis, and Lin (2004) for production basis vs. revenue or consumption basis.
} 
permitted under the GATT/WTO, as long as the rebate rates are no higher than the actual collection rates.

The variation in effective VAT rates arises from modifications to the destination and production basis. Unlike the European Union, where the VAT is on a pure destination basis and VAT rebates on exports are fully credited, in China the destination basis of the VAT is frequently modified by reduction or elimination of VAT rebates on exports to pursue a variety of policy goals, including stabilization, reducing trade frictions, and environmental policy. ${ }^{9}$ The production basis, which is not common worldwide, was adopted originally in order to maximize tax revenue, despite the distortions caused by charging higher taxes to capital-intensive sectors. The tax contains a number of other adjustments and variations which add to its complexity. ${ }^{10}$

As documented by Cui (2003), China implemented the export tax rebate policy in 1985 and established the "full refund" principle in 1988. China implemented a major tax reform in 1994 by replacing the old industrial and commercial standard tax (gong shang tong yi shui) with a new value-added tax with base rates at 13 percent and 17 percent and zero rate on exports. The export rebates increased dramatically after 1994 and the central government was forced to reduce the rebate rates twice in 1995 and 1996 due to budget shortfalls. To counter the negative impact of the 1997 Asian financial crisis and promote exports, China increased the export tax rebates for various products nine times from 1998 to 1999. Since 2003, due to rapidly rising exports and increasing pressure for appreciation of the Renminbi, Chinese government has reduced the export VAT refund rates on many products (see Circular No. 222, 2003). For example, rebates on certain scarce natural resources and ores were reduced or completely eliminated. In 2008, a new round of rebates cut on more than one third of the product categories in the customs tariff code was proposed by Chinese government (see Circular No. 90, 2008). Rebates were eliminated on those products that consume high amounts of energy and resources or cause high levels of pollution in production, and lowered for certain products that tend to cause trade frictions such as textiles, toys, paper and furniture. Over 2002-2008, the average statutory VAT rate is about 16 percent, and the rebate rates range from 0 percent to 17 percent with an average around 12 percent and a standard deviation around 4 percent. Thus the net VAT (VAT minus the rebate)

\footnotetext{
${ }^{9}$ See U.S. International Trade Commission (2008) pp. 148-149.

${ }^{10}$ Liu (2006) contains recent detailed descriptions of the VAT in chapter 3 and the business tax in chapter 5.
} 
has a substantial amount of cross-product and time series variation, which we exploit in our econometric analysis.

The VAT rebate policy on exports in China is complicated and has been changing constantly over time. However, the main method of computing the rebate is rather stable. "Exemption, Credit and Refund" (ECR hereinafter) is the most popular method, especially in the recent years. As specified in Circular No. 7 (2002), almost all manufacturers use the ECR method. ${ }^{11}$ According to Circular No. 7 (2002), the official formula used to calculate VAT payable for general trade and processing exports with imported materials is as follows:

VAT Payable $=$ Output VAT $-($ Input VAT - NCNR $)$

in which Output VAT $=$ Domestic sales amount $*$ VAT levy rate (there is no output VAT on exports); Input VAT is the VAT paid on domestically acquired inputs; and NCNR (the noncreditable and nonrefundable amount) is defined as

$$
\mathrm{NCNR}=(\mathrm{X}-\mathrm{BIM}) *(\mathrm{t}-\mathrm{r})
$$

in which X denotes the value of exports; BIM represents bonded (or tax-free) imported materials; $\mathrm{t}$ is VAT levy rate; and $\mathrm{r}$ is VAT rebate rate. Thus, for the case of exports, the total VAT bill reduces to (NCNR - Input VAT).

The above formula implies that exporters may have incentive to under-report export $(\mathrm{X})$ if $(\mathrm{t}-$ r) is positive, which is true for the partial rebate regime in China. The higher is (t-r), the stronger the incentive for exporters to under-report to the Chinese customs authorities. Therefore, we predict a positive relationship between the China-U.S. trade discrepancy and (t-r), the net VAT rate. ${ }^{12} \mathrm{By}$ a similar argument, there should be a positive relationship between the discrepancy and the Chinese corporate income tax rate, since increased export revenues imply increased total revenues and increased profits.

We expect that the VAT avoidance incentive may be stronger for normal exporters than processing exporters. First, processing exporters are less likely to under-report than normal exporters in general due to stricter enforcement on processing trade at Chinese border. For example, Chinese Customs usually maintain the records for processing trade for at least five years. Second, processing exporters are also less likely to under-report than normal exporters to avoid VAT in particular due to the following reasons. According to the formula (8), processing

\footnotetext{
${ }_{11}^{11}$ Another permissible method, "Refund after Collection," has been rarely used since 2002.

${ }^{12}$ Under-reporting exports has been a popular method to save export VAT in China and has been recommended by some accounting firms (e.g., http://www.britcham.org/upload/publications/151/VATchangesRussell.pdf, page 10).
} 
traders can reduce VAT liability through either understating exports (X) or overstating BIM, while normal traders can only understate exports. Not all exporters are eligible for duty-free treatment of imported inputs. Only exports which qualify for the processing trade have BIM, but "Normal" exporters usually have to pay duty on imports. In a legally allowable tax filing, processing exporters must have exports exceeding the value of BIM. Otherwise the authorities will detect a problem and the duty exemption for the imports may be revoked. In the case of normal exports, there is no duty exemption for imported intermediates, and thus their value does not create a lower bound for under-reporting of exports. Moreover, the ECR method strictly speaking applies only to normal exports and exporters in processing trade with imported materials (type II). Processing exports with supplied materials (type I), in which foreign firms own the bonded imports and the exports produced from them, use the "No collection and no refund" method. This means no VAT on the value-added part of type I processing exports so there is no refund on the domestically purchased inputs. Thus, there is no benefit for misreporting exports associated with misreporting type 1 processing exports. However, since type I processing exports only account for about 10 percent of China's total exports in recent years, the VAT formula discussed in the text describes the most relevant case. For above reasons, normal traders may understate exports more heavily than processing traders.

We also expect larger statistical discrepancy for products with higher domestic firm shares (including SOEs, collective and private firms) than for foreign investment enterprises (FIEs). There are two possible reasons. First, since domestic firms are subject to more strict capital controls, the incentive to under-report exports in order to engage in unrecorded capital export (money laundering) may be greater from them. Second, domestic traders may be more sophisticated about exploiting loopholes in the VAT rebate procedure, or may have closer relationships with Chinese Customs which may reduce the severity of penalties they receive if their misreporting is detected.

Besides VAT, the Chinese corporate income tax, known as enterprise income tax (EIT), also provides an incentive for under-invoicing of exports. However, there are significant differences between the administration of VAT and EIT. Taken together, these suggest that effective EIT rates are more arbitrary and less transparent than VAT rates, and that firms make use of a variety of strategies for avoiding EIT that do not involve under-invoicing of exports. The effective VAT rate (net of export rebate) applying to a given export transaction at a given time can be 
determined simply by identifying the types of goods exported, and identifying these goods by HS number in the appropriate circular. There are many additional factors which determine the rate of EIT. From the mid-1990s through 2007, there have been two different EITs, one for foreign investment enterprises (FIEs) and one for domestic enterprises, with the statutory rate higher for domestic enterprises. Deviations from the standard rate occur for many reasons, including locating in a special economic zone or other similar area; tax holidays for new enterprises; high proportions of output exported; locating in a less-developed region and so on. FIEs are reported to possess substantial bargaining power over the tax rate at the initial stages of a project. This does not exhaust the degree of arbitrariness in the administration of the tax. Local governments may allow a variety of tax breaks on both VAT and EIT. In the case of EIT, local governments receive a certain percentage of the revenue directly, and may choose to rebate part of it for economic development purposes. Moreover, even for tax laws promulgated by the central government, collection, interpretation, and enforcement are conducted at provincial and local levels. The EIT law current for most of our sample period allowed domestic firms to make tax payments based on "deemed profit" rather than actual profit, which can be abused to lower tax payments. There have also been reports of local government authorities pressuring non-FIEs to overstate profits in order to increase revenues. ${ }^{13}$ Due to the above problems of EIT, we choose not to include it into our empirical analysis.

Other factors may also contribute to the under-reporting behaviors at the Chinese border. For example, misreporting of trade data is also one of several methods of moving capital into and out of a country. We treat this subject in a special section below. Another factor behind underreporting of exports at Chinese border might be smuggling. The smuggling of cultural property and antiques has been studied by Fisman and Wei (2009). We do not intend to address this issue because it can be better dealt with in a multiple country context.

\footnotetext{
13 See U.S. International Trade Commission (2007), 64-70, and the additional sources cited therein. Reforms of the EIT, adopted in March 2007 and going into effect January 2008, may mitigate some of the degree of arbitrariness in the statutory application of FIEs. These reforms unify the EIT rate for FIEs and domestic enterprises, and repeal a number of the EIT incentives applying to special situations, in some cases with transition periods. Nonetheless, the situation described in the preceding paragraph applies to the situation for most of our data set, and there is no obvious reason to believe that the nature of provincial and local interpretation and enforcement of the EIT will automatically change under the new tax law.
} 


\subsection{Evasion of capital controls and misreporting at the Chinese border}

Misreporting of trade data is also one of several methods of moving capital into and out of a country. If the true value of exports is higher than that reported to the authorities (i.e. exports are under-invoiced), the difference can be deposited in an overseas account as a method of unreported capital export. Similarly, if the true value of exports is lower than that reported to the authorities (exports are over-invoiced), the difference can be used to provide a paper justification for bringing additional capital into the country. Although there are other methods for concealing capital transactions, such as misstating FDI transactions or the use of underground private banks, a good deal of concealed "hot money" flows into and out of China may take the form of underand over-invoicing of exports.

Chinese capital controls have taken a variety of forms, varying over time. These include controls on portfolio flows, external debts, banking transactions, and, until recently, outward direct investment. Evidence that the capital controls have been historically binding includes both the fact that the composition of capital inflows into China has been heavily weighted towards less-controlled foreign direct investment inflows (Prasad and Wei, 2005) and the persistence of onshore vs. offshore interest rate spreads, though these have narrowed since the beginning of the current episode of Renminbi appreciation in 2005 (Ma and McCauley, 2007).

Lyungwall and Wall (2007), studying capital flight from China, examine several alternative measures of capital flight, using different measures generated from the balance of payments. These measures are in broad agreement that China has experienced net capital flight since at least 1986, which peaked in approximately 1998 and declined to near zero by 2001-2002. The peak of capital flight coincides with the period of extensive bankruptcies and restructuring of state-owned enterprises. We extended the three methods for the period from 2003-2007, using IMF balance of payments data. The results for the period prior to 2003 broadly replicate those of Lyungwall and Wall, who use some data from the China State Administration of Foreign Exchange. Beginning in 2001, we find evidence for net capital inflow into China. This is consistent with anecdotal reports and with a motivation for net inflow due to anticipated appreciation of the Renminbi, which in fact began a process of managed appreciation in July 2005. 
Figure 3 shows the net capital flight from China calculated as a residual (World Bank, 1985), ${ }^{14}$ graphed on the left axis, and showing the reversal from net "hot money" inflow through 2000 to net outflow from 2001 onwards. On the right axis is shown the first difference or change in U.S.-China eastbound direct trade statistical discrepancy (GAP), which is defined as $\ln (\mathrm{M} / \mathrm{X})$ (see second column of Table 1 and equation (9)). We first-difference the gap in order to capture deviations from trend, since we believe the trend is largely determined by other patterns of evasion such as avoidance of VAT. That is, when there is net unrecorded capital flight from China we expect the discrepancy to increase and when there is net unrecorded capital movement into China we expect the discrepancy to decrease. As expected, the two series are positively correlated with a correlation coefficient of 0.48 . The pattern presented here is broadly suggestive of a situation in which under-invoicing of exports from China prior to 2001-2002 may have contributed to an expansion of the observed data discrepancy, while over-invoicing of exports from 2003 onward may have contributed to a narrowing of the discrepancy. If, as is widely believed, the amount of "hot money" inflows into China accelerated rapidly after 2005, we should able to see a narrowing of the trade statistical discrepancy in most recent years. Therefore a year dummy variable using 2002 as benchmark in the econometric model may be indicative for whether such a general pattern exists when we control all other possible misreporting incentive variables. Because the incentive for avoiding capital control pertains to all traders, and does not observably vary by the type of goods traded, it is not able to enter into the econometric specification presented later in the paper directly. One motive for avoiding capital controls is to engage in "round-tripping" of foreign direct investment. This is a practice under which Chinese investors export capital in order to bring it back in again, often through Hong Kong, Macao, or the British Virgin Islands. The incentive for this practice is that policy treatment of foreign investors is in many respects more favorable than treatment of domestic investors, and policy treatment in Hong Kong and Macao is more favorable than in the mainland. As estimated by Xiao (2004), as much as 20 to 30 percent of capital flight from China returns to the country in the form of round-tripping FDI.

\subsection{Incentives for misreporting at the U.S. border}

\footnotetext{
${ }^{14}$ This is defined as (change in external debts + net foreign direct investment + current account balance - change in foreign exchange reserves). Data generated using the other two methods are broadly similar through 2007.
} 
There are incentives for under-reporting and over-reporting imports at the U.S. border. We have discussed before the under-reporting to evade tariffs. The transfer pricing literature suggests that there are incentives to under-price U.S. intra-firm exports to low tax countries and overprice U.S. intra-firm imports from such countries. Most of these studies exploit the cross-country variation in tax rates. In one estimate, Bernard, Jensen, and Schott (2006) estimate that the United States over-reported its imports from China by about $\$ 1.72$ billion in 2004. Since the average U.S. corporate income tax rate in 2005 was about 35 percent on income subject to tax and about 19 percent on total net income. By contrast, the average tariff rate on U.S. imports was about 1.4 percent. Thus, in almost all cases, incentives favor over-reporting at the U.S. border. ${ }^{15}$ However, it is challenging to assign an appropriate corporate income tax rate to different U.S. import transactions based on the available information. Our econometric analysis primarily relies on the data at HS-6-digit product level. Because there is no cross-product variation per se in the statutory corporate income tax rates, we can not test for this hypothesis directly. In our empirical analysis, therefore, we test it indirectly by using the information on related party transactions, which is the U.S. import transaction conducted by related parties within multinationals (between headquarter and an affiliate or between affiliates). The transfer pricing model should, strictly speaking, apply only to the transactions with intra-firm trade. The incentives under this model would imply larger values for imports, since U.S. corporate income taxes are generally higher than Chinese taxes as applied to FIEs. In a misreporting model, the presence of either corporate income tax gives rise to a positive discrepancy $(M>X)$. The incentives for over-reporting imports are greater than the incentives for under-reporting exports, though, because of the differences in the tax rates. It may also be the case that multinational firms are more sensitive to the relative incentives than firms making arms' length comparisons, and more sophisticated in avoiding enforcement. Any of these considerations, or all of them taken together, would lead us to predict that the statistical discrepancy is higher for related-part trade.

An additional feature of the U.S. customs valuation system leads us to expect that in the presence of tariffs, the trade data gap could be smaller for transactions involving related parties. It is often the case that a U.S. importer acquires an imported good by means of a series of transactions between different entities, with each entity re-selling the good to the next one at a

\footnotetext{
15 Data on corporation returns with net income is available from the Internal Revenue Service at http://www.irs.gov/taxstats/article/0,,id=170693,00.html
} 
higher price. In this case, it is permissible to report the lower sale value on the first of the series of transaction for the purposes of customs valuation. This practice, which is known informally as the "First Sale Rule", has received increasing attention recently. ${ }^{16}$ The different entities involved in a series of sales may not necessarily be related parties to the ultimate importer; they may simply be middlemen. However, it is more likely that transactions can be structured in such a way as to take advantage of the First Sale Rule in organizations which already consist of multiple legal entities, such as multinational firms. Thus, we expect that the U.S.-China trade data gap will be lower for transactions involve both high tariffs and between related parties than transactions involve both low tariff and between related parties.

We capture the possibility that related-party transactions may be more sensitive to the tariff, for whatever reason, by including in our regressions an interaction term between U.S. import tariffs and related party transaction share in total U.S. imports from China.

\section{Data Sources and Descriptive Statistics}

Our strategy is to make use of variation across disaggregated trade data at the Harmonized System subheading level (HS-6), the finest level at which consistent international comparisons can be made. The goal is to identify statistically significant and economically important correlations between the observed discrepancies and the incentives for misreporting, as well as any potential differences in enforcement associated with different firm types and trade policies. Our measure of the trade discrepancy excludes re-exports and transshipment through Hong Kong and other third countries. Thus, we concentrate our analysis on discrepancies between China reported direct exports to the United States and U.S. reported direct imports from China. Our explanatory variables capturing the economic incentives for misreporting include, tariff imposed at the U.S. border, the difference between the Chinese VAT collection rate and rebate rate, the shares of different enterprise types and trade regimes in China reported direct exports to the U.S., and the share of related-party trade in U.S. reported imports from China.

U.S. reported direct imports from China are taken from unpublished records obtained from the U.S. Census Bureau, which identify goods shipped directly from ports within China (direct shipment) and whether the goods entered into commerce (cleared customs) in a third country en

\footnotetext{
${ }^{16}$ In January 2008, the Bureau of Customs and Border Protection proposed eliminating the First Sale Rule. This proposal was temporarily postponed by Congress by a provision of the Food, Conservation and Energy Act of 2008 in May. Further background on the First Sale Rule may be found in Federal Register (2008).
} 
route to the United States (re-exports) or otherwise transited through a third-country port (transshipment). The data cover all U.S. direct imports from China (direct shipment) during 1995-2008 at the HS-6 level. China reported direct exports to the United States are taken from official China Customs trade statistics at HS-6 level. In order to match data reported from U.S. side, all re-exports through Hong Kong or other third countries have been eliminated. Details on the unpublished U.S. shipping records, the data sources and adjustments made to official China Customs statistics are described in Ferrantino and Wang (2008). Our measure of statistical discrepancies between U.S. reported direct imports from China and China reported direct exports to the U.S. is computed as :

$$
G A P_{i t}=\ln \left(M_{i t}^{U S}\right)-\ln \left(X_{i t}^{C H}\right)
$$

where $M$ is U.S. reported direct imports from China; $X$ is China reported direct exports to the U.S.; $i$ represents product; and $t$ represents year. This measure is slightly different from the one defined in our theoretical model as in formula (6). In our theory, we assume that the discrepancy arises from the difference in reported unit values or prices $(\mathrm{P})$. Multiplying both the numerator and denominator of $\left(P_{M}-P_{X}\right) / P$ in formula (6) by $\mathrm{Q}$ yields the difference in reported trade values divided by the true value. For values of the discrepancy that are not too large, this is approximately equivalent to the measure given in (9). ${ }^{17}$

Summary statistics for our measure of U.S.-China trade data discrepancy are reported in Table 1. There are three notable features in the data. First, the mean of GAP is near zero in 1995, implying that the data match fairly well. From 1997 onward, the mean discrepancy is positive, reaching its trade-weighted peak in 2002, then starts to decline. Second, the size of the discrepancies varies significantly across HS-6 subheadings, as reflected by the large size of the coefficient of variation (standard error/mean). Finally, despite the overall positive discrepancy, over 40 percent of the discrepancies at the HS-6 level are actually negative, demonstrating that the factors influencing the discrepancies are very complex and may operate in the opposite direction. Figure 4 depicts the nonparametric kernel density distribution of GAP for three years:

\footnotetext{
${ }^{17}$ If we assume that the U.S. reports the true import value $(M)$ and $(M-X) / M$ is small, $G A P=\ln (M)-\ln (X)=-$ $\ln (\mathrm{X} / \mathrm{M})=-\ln [(\mathrm{X}-\mathrm{M}) / \mathrm{M}+1) \sim-(\mathrm{X}-\mathrm{M}) / \mathrm{M}=(\mathrm{M}-\mathrm{X}) / \mathrm{M}$.
} 
1995, 2002 and 2008. The distribution has wide range but highly concentrated around zero and becomes less and less dispersed over time. ${ }^{18}$

Table 2 shows some descriptive statistics of the covariates over sample years 2002-2008. The trade weighted average of these explanatory variables is listed on the second column. The next four columns report some statistics at HS-6 product level. We also calculate the average GAP at HS-6 level for the products with high and low value of these explanatory variables (compared to their mean) and list them on the last two columns. China VAT rebate rate data are obtained from the Department of Taxation Policy, Ministry of Finance, and the State Administration of Taxation. These include statutory collection rates and refund rates for each product at HS-8 or higher levels from 2002 to 2008 . When VAT statutory or rebate rates change in the middle of a year, we use the weighted average, weighted by the numbers of days in each period for a given year. Data at HS-8 level are then averaged to HS-6 level. Although only seven year data are available, the data show clearly that the average discrepancies for products with high net VAT collection rates are significantly higher than the discrepancies for products with low net VAT collection rates $(0.50$ vs. 0.18$)$, which is consistent with our expectation that higher net VAT leads to under-reporting exports at Chinese border and hence higher GAP.

U.S. tariffs on merchandise imported from China are computed using USITC internal data, as the ratio of calculated duties collected to customs value of U.S. imports from China for consumption at the HS-6 level. The data show that in general, U.S. tariff rates on imports from China are about 4 percent for the average HS-6 subheading, with peaks at around 80 percent. The average discrepancy for products with high tariff rates is much lower than the average discrepancy for products with low tariff rates $(0.03$ vs. 0.41$)$. This implies a negative association between the GAP and U.S. tariff rates. This is consistent with the tariff evasion hypothesis: higher U.S. import tariffs lead under-reporting imports at the U.S. border and hence lower GAP. The related party shares of U.S. imports from China are generated from the confidential Census data which distinguish intra-firm (related party) trade from arms' length trade. ${ }^{19}$ It is on average about $24 \%$ of the total imports ( $11 \%$ if based on the simple average at HS- 6 level). ${ }^{20}$ This implies

\footnotetext{
${ }^{18}$ The figure is based on the Epanechnikov kernel function. The $5^{\text {th }}$ and $95^{\text {th }}$ percentile of GAP are about -2.7 and 3.4 respectively over the years 1995-2008.

${ }^{19}$ Comparable publicly available data are available at http://sasweb.ssd.census.gov/relatedparty/.

${ }^{20}$ The average share at HS-6 level $(0.11)$ is lower than the aggregate share because a large number of products have no related-party trade. For example, the overall share of related party imports among U.S. imports from China in
} 
that U.S.-China direct trade is dominated by arms' length transactions. Although the statistical discrepancies are similar for products with high and low shares of intra-firm trade (27\%), we do find some evidence for positive correlation between GAP and related party share in our regressions.

Finally, Table 2 also presents the descriptive statistics for the shares of Chinese direct exports to the U.S. by different types of enterprises and trade regimes. These data are computed from official China Customs trade statistics at HS-6 level. The trade regimes are classified into normal trade and processing trade; while firm types are classified into domestic firms and FIEs. ${ }^{21}$ The average GAPs for high and low shares support strongly our hypothesis that processing traders and FIE firms are less likely to under-report exports at Chinese border. ${ }^{22}$

Table 2 does not include any data for corporate income tax rates in either China or the United States. While we collected some data for each of these variables, they are problematic from an empirical standpoint. In the case of the Chinese EIT, we have a sample for five years of firmlevel data from the Chinese National Bureau of Statistics, containing over 100,000 observations. Of these 16 percent of the observations report negative profits, but 41 percent of the observations with negative profits report positive income tax. As noted above, there are various reasons to believe that collection of revenues under the EIT is at least somewhat arbitrary, so that firms' incentives are substantially de-linked from the published tax rates. We consider the prevalence of positive collections for negative profit firms to be consistent with this observation. Reasonable aggregations of the data by industry in fact make the problem worse.

In the case of the United States, the difficulty is conceptual. The Internal Revenue Service makes publicly available corporate income tax data according to the NAICS classification system for a number of years, from which we are able to compute several measures of the effective U.S. corporate income tax rate by industry of goods produced. However, the measure appropriate in our empirical analysis is the effective corporate income tax rate for the importing

2005 is 25.8 percent. Intra-firm imports from China highly concentrate in certain categories of electronic equipment and precision instruments.

${ }^{21}$ To be parsimonious, we do not distinguish the two types of processing trade (toll and contract processing). For firm types, we do not distinguish either the different types of domestic firms (e.g., SOE, collective and private firms) or the different types of foreign firms (wholly foreign owned and equity joint ventures). Statistically tests do not imply significant differences between these finer categories.

22 Please note that the trade weighted shares of processing trade and trade by FIE firms are much bigger than the corresponding average shares at the HS-6 level (simple average). This can be explained by the fact that many HS-6 lines with small trade flows are dominated by domestic normal exports, and larger trade flows in the lines are dominated by FIE processing exports. 
industry. This is in many cases different from the industry of goods produced. Many traded goods are intermediate goods, and the importing firms are in many cases wholesalers and retailers rather than manufacturers. To get around this problem, we imputed a corporate tax rate for the typical importer of a product category, using input-output tables. This procedure involves a two-step concordance, from 3-digit NAICS to the classification used in BEA's input-output tables, then to HS-6. At the end of this procedure, we have some doubts as to whether we have adequately identified the appropriate U.S. corporate income tax rate applying to a "typical" importer of a given HS-6 good.

Our attempts to use the corporate income tax data for China and the United States almost uniformly produced poor results. Because of the data and conceptual issues involved in measuring these rates, we thus exclude the variables from our analysis. ${ }^{23}$

\section{Econometric Analysis}

We relate China-U.S. trade statistics discrepancies to the economic incentives of misreporting and other possible determinants. The formal econometric specification is given in following equation (or by variation to be noted in discussion).

$$
G A P_{i t}=\beta_{o}+\beta_{1} V A T_{\mathrm{it}}+\beta_{2} \text { Tariff }_{\mathrm{it}}+\beta_{3} \text { Related }_{-} \text {share }_{i t}+\mathbf{X} \boldsymbol{\gamma}+a_{i}+a_{t}+e_{i t}
$$

where $\beta$ and $\gamma$ are the coefficient to be estimated; VAT is Chinese VAT rate on exports net of rebate; Tariff is U.S. tariff rate on imports from China; Related_share is the share of related party trade in total U.S. imports from China; $\mathbf{X}$ is a vector of other explanatory variables including Chinese export shares by trade regimes and firm types and their interactions with other variables, as well as the interaction between tariff and related party share; $a_{i}$ is product fixed effect at HS 6digit level; $a_{t}$ is year dummy; and $e_{i t}$ is the error term.

The dependent variable is always GAP as defined in Equation (9). We assume that net VAT rates, Chinese trade regime and firm type variables only affect the magnitude of export data reported at Chinese border; while U.S. import tariffs and related party trade share only affect the magnitude of import data reported at the U.S. border. All share and rate variables are divided by 100 so that each has a domain of $[0,1]$. We run both OLS and fixed effects panel regressions at HS-6 level. We also check the robustness of our results to other specifications such as regressions on first differenced data and quantile regressions. Only years 2002-2008 are covered

\footnotetext{
${ }^{23}$ The results and summary data for the corporate income tax variables are available upon request from the authors.
} 
by our regressions due to unavailability of VAT data in earlier years. All regressions include year dummies.

\subsection{Basic results}

Major regression results are reported in Table 3. The first regression is the pooled data regression without any interaction term. The second regression is similar to the first one but uses HS 6-digit product fixed effects. The last two columns are the pooled data and fixed effects regressions with some interaction terms. All the regressions cover years 2002-2008.

The results generally support our misreporting incentive model outlined in section II. All variables have the signs predicted by theory. The coefficients of China's net VAT rate are always positive and highly significant across different specifications. This clearly indicates a positive correlation between China's net VAT rates and GAP (or negative correlation between VAT and China reported exports if we hold U.S. reported imports fixed). It indicates that avoiding VAT tax may be one of the primary economic incentives for firms operating in China to under-report their exports to Chinese Customs authorities.

These estimates are not only statistically significant but also economically large. Let us take the results in Column (2) of Table 3 as an example. The results imply that one percentage increase in China's net VAT rate (due to reduction of VAT rebate rate) will cause about a 3.73 percent increase in GAP (i.e., $\exp ^{(3.66 / 100)}-1$ ). In other words, one percentage increase in net VAT leads to a 3.73 percent decrease in China reported exports if we keep U.S. reported import data fixed. Given the trade-weighted average VAT in Table 2 (i.e., 4\%), this implies $14.9 \%$ underreporting of Chinese exports due to VAT avoidance (i.e., 3.73*4\%). Based on the total direct exports from China to the U.S. in 2008 (230.4 billion in current dollars), this amounts to 34.33 billion dollars of under-reporting of exports (i.e., 230.4*14.9\%) and 1.37 billion dollars loss in Chinese VAT revenue from the direct trade with U.S. in 2008 alone (i.e., 34.33*4\%). Also, the 14.9 percent gap implied by VAT avoidance is large compared to the 21 percent overall gap over 2002-2008 as reported in Table 1.

The regression results also suggest there may be tariff evasion at the U.S. border, indicated by the negative coefficients of U.S. import tariff rate, which varies in statistical significance depending on the specification. The estimate in column (2) implies that if we hold export data fixed, one percentage increase in U.S. import tariffs will lead to a $1.75 \%$ percent decrease in U.S. 
reported imports from China (i.e., $\left.\exp ^{(-1.77 / 100)}-1\right)$. Given the trade-weighted average tariff in Table 2 (i.e., 3\%), this implies 5.25\% under-reporting of U.S. imports due to tariff avoidance (i.e., 1.75*3\%). Based on the total direct U.S. imports from China in 2008 (261.74 billion in current dollars), this amounts to 13.74 billion dollars under-reporting in imports (i.e., $261.74 * 5.25 \%$ ) and 0.41 billion dollars loss in U.S. tariff revenue from the direct trade with China in 2008 alone (i.e., 13.74*3\%). Taking together the under-reporting of Chinese exports due to VAT avoidance and the under-reporting of U.S. imports due to tariff evasion, the net effect is a gap of $9.67 \%$ (i.e., $14.92 \%-5.25 \%$ ). This can explain nearly half of the overall 21 percent gap as shown in Table 1.

The related-party share variable is always positive and significant at a $10 \%$ level in Table 3. This suggests that multinational firms are more likely than national firms to engage in misinvoicing, ceteris paribus. The result can also be interpreted as evidence for traditional transfer pricing, under which imports are over-valued at the U.S. border to transfer taxable income from the country with high rates (United States) to the country with lower rates (China). It is relevant to compare the cases for which the related-party share is 0 or 100 percent, since most HS-6 subheadings approach one of these two extremes. Compared on this basis, related-party transactions have a data discrepancy at least 18.6 percent greater than arms' length transactions (i.e., $\exp (0.17)-1$, based on the second regression in Table 3). Again, this result is economically large.

In considering the results by firm types and trade regimes, the omitted trade regime (firm type) category is normal trade (domestic firms). Our results imply that China reported exports are smaller for normal exports than for processing exports, and for domestic firms than for FIEs if we hold U.S. reported imports constant. This implies that normal exporters and domestic firms are more likely to under-report exports at Chinese border than processing exporters and FIEs. This is consistent with our discussion in section II. $^{24}$

In columns (3) and (4) of Table 3, we add three interaction terms. The first two are between China's net VAT rate and share of processing exports and share of FIEs. The third one is between U.S. import tariffs and related party share. The estimated coefficient of net VAT and

\footnotetext{
${ }^{24}$ There is a substantial overlap between exports categorized by firm type and by customs regime. Exports of FIEs are more likely to be processing exports, and exports of domestic firms are more likely to be normal trade. In order to take account of possible correlation between the two share variables, we ran additional specifications in which firm type and trade regime were combined to create two dimensional categories. The results of these specifications are qualitatively similar to those reported and are available upon request.
} 
processing export share interaction implies that tendency to under-invoice Chinese exports to avoid VAT is smaller for goods heavily dominated by processing exports. Based on column (4), one percent increases in the net VAT implies a 4.12 percent increase in the statistical discrepancy for a product traded as normal exports by domestic firms, and a 0.98 percent increase (i.e., 4.123.14) for a product traded as processing exports by domestic firms. The interaction of VAT with FIE trade share is not significantly different from zero. This says that the incentives of VAT avoidance do not seem to be different among different firm types, although their avoidance behavior is different in general as indicated by the coefficients of the share variables in level (without interactions). The interaction of related party share with U.S. import tariffs negatively affects GAP and is highly significant in Table 3. This is consistent to our expectation based on the discussion of the U.S. Customs' First Sale Rule. It may also reflect other accounting practices that are more widespread among multinational firms.

In the last two columns of Table 3, the coefficient estimate for the U.S. import tariff is significant only in pooled data regression but becomes insignificant in the HS-6 fixed effect regression. There are two reasons for this. First, there is little "within" or time-series variation in tariffs (less than one third of the "between" variation across HS-6 categories). ${ }^{25}$ Second, after we include the interaction between tariff and related party share, the action moves to the interaction between the tariff and related-party share. This suggests that for related parties the reduction in U.S. reported imports is more on the order of 6 percent for each one percent increase in the import duty. This is consistent with the possibility that U.S. multinational firms are able to more conveniently undervalue imports to avoid tariffs, either by using the First Sale Rule mechanism or by some other procedures. If we assume that tariff and related party share are uncorrelated, the t-statistics for the overall effect of tariff can be evaluated asymptotically since the samples are large. ${ }^{26}$ Evaluated at the mean of the data, the tariff is significant at $3 \%$ level for the last regression in Table 3.

The dummy variables for years indicate a declining time trend from 2004 onwards. This is consistent with the behavior of the raw data in Figure 2a and Table 1. The time trend may also be interpreted in a rough way as corroborating the evidence that some of the discrepancy is due to avoidance of capital controls, if we accept the evidence that the incentives to avoid capital

\footnotetext{
${ }^{25}$ By comparison, the within variations of other covariates are similar to their corresponding between variations. ${ }^{26} \operatorname{var}(\mathrm{aX}+\mathrm{bY})=\mathrm{a}^{\wedge} 2 * \operatorname{var}(\mathrm{X})+\mathrm{b}^{\wedge} 2 * \operatorname{var}(\mathrm{Y})+2 \mathrm{ab} * \operatorname{cov}(\mathrm{X}, \mathrm{Y})=\mathrm{a}^{\wedge} 2 * \operatorname{var}(\mathrm{X})+\mathrm{b}^{\wedge} 2 * \operatorname{var}(\mathrm{Y})$ if $\operatorname{cov}(\mathrm{X}, \mathrm{Y})=0$
} 
controls have favored movement of "hot money" into China, and thus a lowering gap, during the period covered by our data. The fact that the gap remains positive suggests that the incentive for VAT evasion continues to outweigh the incentive to use over-invoicing as a means of concealing capital inflows.

We obtain relatively small values of $\mathrm{R}^{2}$ in Table 3 . This is not unusual when working with highly disaggregated trade data. Comparable estimates, aggregating all variables from HS 6digit to HS 2-digit, raise the estimated $\mathrm{R}^{2}$ from less than 0.03 to about 0.11 .

\subsection{Alternative econometric specifications}

To check the robustness of our results, we run regressions with other econometric specifications. For all these regressions, we do not include any interaction terms to ease interpretation. The results are reported in Tables 4 and 5. First, we drop 5\% outliers of GAP from both sides of the distribution. Our main findings hold well as shown by the first two columns of Table 4. The tariff variable turns insignificant in the HS-6 fixed effect regression but is still highly significant in the pooled data regressions. Second, as an alternative method to the fixed effect regression, we also run regression based on first-differenced data. Fixed effect regression is more efficient when the idiosyncratic error term $e_{i t}$ in formula (10) is serially uncorrelated; while first difference is more efficient when $e_{i t}$ follows a random walk. ${ }^{27}$ Based on the test proposed by Wooldridge (2002), the null hypothesis of no serial correlation in the error term is rejected. Therefore it is useful to run both the fixed effects and first-difference regressions. The results from the first difference regression are reported on the last column of Table 4. As we can see, the results are similar to those from the corresponding fixed effect regression (see the second column of Table 3). We also run the cross section regressions year by year for 2002-2008. The results are largely in agreement with the previous pooled data regressions. To save space, these cross section analysis results are not reported but available upon request.

We also run quantile regressions, where the conditional quantile will be taken to be linear in $X$. The standard linear regressions summarize the average relationship between the outcome variable of interest and a set of regressors, based on the conditional mean function: $E(Y \mid X)=\beta X+u$. This provides only a partial view of the relationship. A more complete

\footnotetext{
${ }^{27}$ Given that our sample period is very short (only seven years), it is not feasible to test directly for the presence of a random walk.
} 
picture would provide information about the relationship between $\mathrm{Y}$ and $\mathrm{X}$ at different points in the conditional distribution of $\mathrm{Y}$. Quantile regression is a statistical tool for building such a picture. In addition, quantile regression is robust to outliers; while standard linear regression based on conditional mean can be severely influenced by outliers. In linear regression, the regression coefficient measures the change in $\mathrm{Y}$ produced by a one unit change in $\mathrm{X}$. The quantile regression coefficient measures the change in a specified quantile of y produced by a one unit change in $\mathrm{X}$.

Table 5 reports the results from simultaneous quantile regressions for the $10^{\text {th }}, 15^{\text {th }}, 50^{\text {th }}, 75^{\text {th }}$ and $90^{\text {th }}$ quantiles. To address the unobserved heterogeneity problem, we use first differenced data. ${ }^{28}$ The standard errors are obtained by bootstrapping methods with 100 replications. ${ }^{29}$ These results offer some interesting findings. Most importantly, the estimated coefficients vary with different quantiles of GAP. This is especially evident for VAT variable. The coefficient of VAT variable increases from 1.398 at the $10^{\text {th }}$ quantile (actually insignificant) to 7.416 at the $90^{\text {th }}$ quantile. This says that VAT avoidance is more prominent for the products with higher GAP. This provides further support for our hypothesis that VAT avoidance leads to under-reporting of exports at the Chinese border (hence higher GAP). The comparable OLS estimate (4.227) can be found on the last column of Table 4 (i.e., the first difference regression). Figure 5 provides a sharp contrast between the estimates from OLS and quantile regressions. The figure summarizes the estimated coefficients of VAT variable for each quantile at 0.05 increments (curved solid line) and the corresponding 95\% confidence interval bands (shaded area). The dashed straight line represents the estimates from OLS with the dotted line as the $95 \%$ confidence interval bands. The figure shows that the OLS estimates are significantly lower than quantile estimates when GAP is low but significantly higher than quantile estimates when GAP is high. This figure highlights that a linear regression might not be an optimal solution to assess this relationship. The tariff variable tells a similar story. As shown by Table 5, the coefficient of tariff is higher and more significant for lower GAP. This pattern is consistent with our tariff evasion story.

\footnotetext{
${ }^{28}$ Strictly speaking, quantile regression on first-differenced data is consistent only if the stochastic error terms $e_{i t}$ is independently and identically distributed (iid) conditional on $\mathrm{X}$ and unobserved heterogeneity $\left(a_{i}\right)$. This is a fairly strong assumption. It is still an open research question regarding how to address unobserved heterogeneity in quantile panel regression. Standard demeaning techniques rely on the fact that expectations are linear operators, which is not the case for conditional quantiles. Recent studies on this topic include Koenker (2004) among others.

${ }^{29}$ Standard errors can be obtained with asymptotic and bootstrapping methods. Both methods provide robust results (Koenker and Hallock, 2001), with the bootstrap method preferred as more practical (Hao and Naiman, 2007).
} 
We also consider the possible nonlinear impact of trade taxes on the discrepancy by including quadratic terms for the export tax and import tariff. When the quadratic term of export tax is included, the estimated coefficients of both export tax and its squared term are positive, but at least one of them is insignificant. Adding the quadratic term for import tariffs turns both import tariff and its squared term insignificant. We conclude there are no significant nonlinear effects and proceed without higher-order terms.

\subsection{Other auxiliary regressions}

We have found strong evidence for mis-reporting trade values at both Chinese and the U.S. borders. A natural question to ask is whether the mis-reporting is due to mis-reporting product quantity, price or unit value, or misclassification from products with high tax rates to products with low tax rates (see, e.g., Fisman and Wei, 2004). Because we do not have the quantity and unit value data in unpublished U.S. shipping records obtained from U.S. Census, we are only able to test for the hypotheses of misclassification. We created two new explanatory variables: average U.S. tariffs and China's net VAT rate for similar products, i.e., other HS 6-digit products within an HS 4-digit category. These variables yield weak results, thus we do not report the results and conclude that by this test at least we do not find significant evidence of misclassification.

We check the robustness of our results reported in previous subsections to a series of subsamples. For example, we divide the regression data set into three sub-samples based on Rauch's product classification: homogenous, reference-priced and differentiated goods. Javorcik and Narciso (2008) find stronger evidence of tariff evasion for differentiated products at the borders of some East European countries. We find some similar evidence for early period of time but it is not robust to the inclusion of recent years. These results, not reported here, are available upon request.

Finally, it is possible that China's export taxes and U.S. import tariffs may be endogenous and this can lead to biased estimates in the coefficients. The endogeneity problem of export tax (import tariffs) is more likely for export (import) flows, but is less likely for their discrepancy. Policymakers are likely to choose these policy instruments in order to achieve certain levels of exports and imports. Our dependent variable is the value of the discrepancy, which is unlikely to be a policy target of high concern, and unlikely to be taken into account when setting China's 
VAT. Moreover, U.S. tariffs are heavily influenced by other factors, such as multilateral negotiations under the WTO. So it is unlikely that U.S. tariffs are affected by the U.S.-China trade data discrepancies. Therefore, in the context of our study, the endogeneity of trade taxes should not be a serious problem.

\section{Concluding Remarks}

We believe that the discrepancies in international trade data are more than simply an inconvenience for empirical researchers. They may, in fact, reveal a significant amount of information about the incentives of exporters and importers who are confronted with taxes, tariffs, and capital controls, and have incentives to evade them. In order to highlight these incentives, we develop a simple model to explain the behaviors of trading firms facing two decisions: how much to misreport to exporting countries, and how much to misreport to importing countries. The model, though similar to those in the transfer pricing literature which considers the single decision of the level of the transfer price, has some additional implications for trader behaviors and can accommodate both arms' length traders and related-party traders. The incentives for misreporting are similar for both types of traders. The model indicates that an exporter has an incentive to under-report the value of exports in the presence of either a corporate income tax or a value-added tax. This incentive is increasing in the level of the actual collect rate of these taxes and when there are incentives to export capital to evade capital controls. The model also predicts that importer has an incentive to understate the value of imports to evade tariffs and overstate the value of imports when the corporate income tax is higher than import tariff rate. These incentives are decreasing in the intensity of enforcement.

We then test the model using the discrepancies between China reported direct exports to the U.S. and U.S. reported direct imports from China, China's net VAT rates on exports, U.S. import tariff and related party trade share in U.S. imports from China at HS 6-digit from 2002 to 2008. Our empirical results are generally consistent with the predictions of our theoretical model. There is strong statistical evidence for under-reporting of exports at Chinese border to avoid paying VAT. Normal exports and exports by domestic firms are more likely to have understated values than processing exports and exports by FIEs. These patterns have reasonable explanations in terms of the incentives facing different kinds of firms. Processing exporters may be subject to more intense enforcement, and can avoid VAT by the alternative method of over-reporting 
bonded imported materials. Domestic firms may be subject to both weaker customs enforcement and more stringent capital controls than FIEs. We also provide some evidence of tariff evasion at the U.S. border, and indirect evidence of transfer pricing and over-reporting at Chinese border to avoid capital controls restricting inflows of capital into China. The widespread avoidance of VAT by exporting firms is of particular importance for Chinese policy, since it suggests that it may be difficult to obtain very strong results from the present practice of using variations in the VAT rebate as a multi-purpose policy instrument. 


\section{References}

Bernard, Andrew B., Bradford J. Jensen, and Peter K. Schott, 2006. Transfer Pricing by U.S.Based Multinational Firms. NBER Working Papers No. 12493.

Bhagwati, J., 1964. On the Underinvoicing of Imports. Bulletin of the Oxford University Institute of Economics and Statistics 26(4): 389-397.

Bipartisan China Currency Action Coalition, 2007. Before the Office of the United States Trade Representative: Petition for Relief under Section 301(a) of the Trade Act of 1974, as Amended, May 17.

Circular No. 7, 2002. Notice on Further Implementing the "Exemption, Credit and Refund" System of Export Tax Rebate, issued jointly by the Ministry of Finance and the State Administration of Taxation of China in October 2002.

Circular No. 222, 2003. Notice on Adjusting Export Tax Rebate Rates, issued jointly by the Ministry of Finance and the State Administration of Taxation of China in October 2003.

Circular No. 90, 2007. Notice on Adjusting Export Tax Rebate Rates for Certain Commodities, issued jointly by the Ministry of Finance and the State Administration of Taxation of China on June 19, 2007.

Cui, Zhiyuan, 2003. China's Export Tax Rebate Policy. China: An International Journal 1(2): 339-349.

Federal Register, 2008. Proposed Interpretation of the Expression 'Sold for Exportation to the United States' for Purposes of Applying the Transaction Value Method of Valuation in a Series of Sales 73(16): 4254-4264. Washington: U.S. Government Printing Office.

Feenstra, Robert C., Wen Hai, Wing T. Woo, and Shunli Yao, 1999. The U.S.-China Bilateral Trade Balance: Its Size and Determinants, The American Economic Review, May 1999, pp. 338342.

Ferrantino, Michael J., and Zhi Wang, 2008. Accounting for Discrepancies in Bilateral Trade: The Case of China, Hong Kong, and the United States. China Economic Review 19(3): 502-520.

Fisman, Raymond, and Shang-Jin Wei, 2004. Tax Rates and Tax Evasion: Evidence from "Missing Imports" in China. Journal of Political Economy 112(2): 471-496.

Fisman, Raymond, Peter Moustakerski, and Shang-Jin Wei, 2008. Outsourcing Tariff Evasion: A New Explanation for Entrepôt Trade. The Review of Economics \& Statistics 90(3): 587-592.

Fisman, Raymond, and Shang-Jin Wei, 2009. The Smuggling of Art, and the Art of Smuggling: Uncovering the Illicit Trade in Cultural Property and Antiques. American Economic Journal: Applied Economics 1(3): 82-96. 
Fung, K.C., and Lawrence J. Lau, 1998. The China-United States Bilateral Trade Balances: How Big Is It Really? Pacific Economic Review 3(1): 33-47.

Fung, K.C., and Lawrence J. Lau, 2004. Estimates of Recent United States-China Bilateral Trade Balances. Working Paper.

Fung, K.C., Lawrence J. Lau, and Yanyan Xiong, 2006. Adjusted Estimates of United StatesChina Bilateral Trade Balances -An Update. Pacific Economic Review 11(3): 299-314.

Gehlhar, Mark J., 1996. Reconciling Bilateral Trade Data for Use in GTAP. GTAP Technical Paper No. 10. West Lafayette, IN: Purdue University. October.

Hao, Lingxin, and Daniel Q. Naiman, 2007. Quantile Regression. Sage Publications, Thousand Oaks.

Javorcik, Beata Smarzynska, and Gaia Narciso, 2008. Differentiated Products and Evasion of Import Tariffs. Journal of International Economics 76(2): 208-222.

Koenker, Roger, 2004. Quantile Regression for Longitudinal Data. Journal of Multivariate Analysis 91(1): 74-89.

Koenker, Roger, and Kevin F. Hallock, 2001. Quantile Regression: An Introduction. Journal of Economic Perspectives 15(4): 143-156.

Lin, Z. Jun, 2004. Evaluating the VAT in China. International Tax Journal 30(1): 65-83.

Liu, Zuo, 2006. Taxation in China, Singapore: Thomson Learning.

Lyungwall, Christer, and Zijian Wang, 2008. Why is Capital Flowing out of China? China Economic Review 19(3): 359-372.

Ma, Guonan, and Robert N. McZCauley, 2007. Do China's Capital Controls Still Bind? Implications for Monetary Autonomy and Capital Liberalization. Bank for International Settlements Working Paper No. 233 (August).

Mishra, Prachi, Arvind Subramanian, and Petia Topalova, 2008. Policies, Enforcement, and Customs Evasion: Evidence from India. Journal of Public Economics 92(10-11): 1907-1925.

Palley, Thomas, 2005. The China Currency Problem: A Reply to Albert Keidel Comments given at a symposium titled "China's Currency: Not the Problem," Carnegie Endowment for International Peace, Washington, DC, June 24.

Prasad, Eswar, and Shang-Jin Wei, 2005. The Chinese Approach to Capital Inflows: Patterns and Possible Explanations. IMF Working Paper No. 79. 
Rauch, James, 1999. Networks versus Markets in International Trade. Journal of International Economics 48(1): 7-35.

Swenson, Deborah L, 2001. Tax Reforms and Evidence of Transfer Pricing. National Tax Journal. 54(1): 7-25.

Tsigas, Marinos E., Thomas W. Hertel, and James K. Binkley, 1992. Estimates of Systematic Reporting Bias in Trade Statistics. Economic Systems Research 4(4): 297-310.

U.S. Department of Commerce, Office of the United States Trade Representative, and Ministry of Commerce, People's Republic of China, 2009. Report on the Statistical Discrepancy of Merchandise Trade between the United States and China. Hangzhou, P.R.C., October.

U.S. International Trade Commission, 1998. Implications for U.S. Trade and Competitiveness of a Broad-Based Consumption Tax. Publication 3110 (June), Washington, DC.

U.S. International Trade Commission, 2007. China: Description of Selected Government Policies and Practices Affecting Decision Making in the Economy. Publication 3978 (December), Washington, DC.

Wang, Zhi, Mark Gehlhar, and Shunli Yao, 2006. Estimating Hong Kong Re-export Markups and Reconciling Trade Statistics from China, Hong Kong and Their Major Trading Partners - A Mathematical Programming Approach. The $9^{\text {th }}$ GTAP conference paper, June.

West, Loraine A., 1995. Reconciling China's Trade Statistics. IPC Staff Paper No. 76, International Program Center, Population Division, U.S. Bureau of the Census, Washington, DC.

Whalley, John, and Li Wang, 2007. Unified Enterprise Tax and SOEs in China. NBER Working Paper No.12899.

Wooldridge, Jeffrey M., 2002. Econometric Analysis of Cross Section and Panel Data. Cambridge, MA: MIT Press.

Xiao, Geng, 2004. People's Republic of China's Round-Tripping FDI: Scale, Causes and Implications. Hong Kong Institute of Economics and Business Strategy Working Paper, July. 
Figure 1a. Eastbound U.S.-China trade 1978-1993

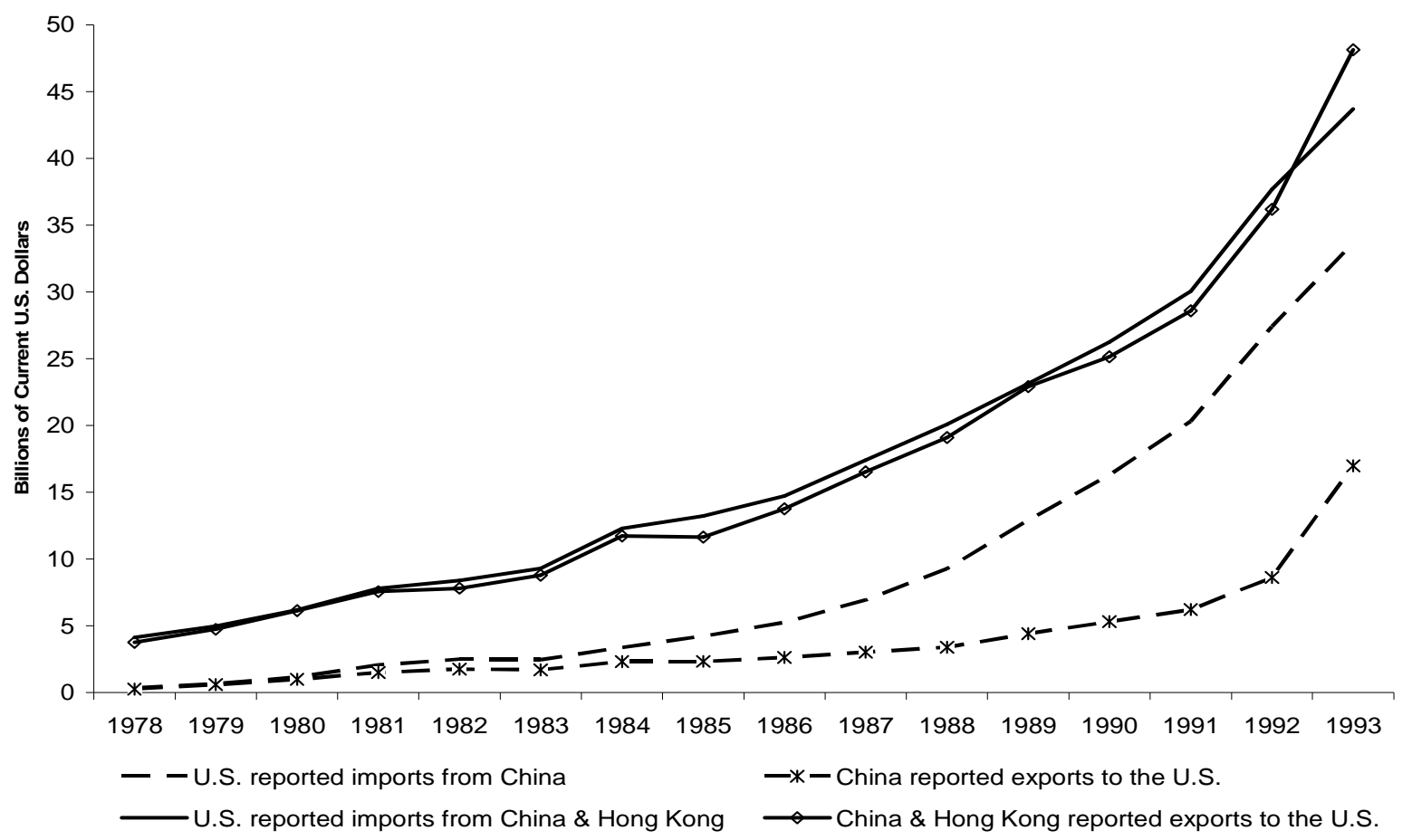

Figure 1b. China-Hong Kong Exports to United States, 1995-2008

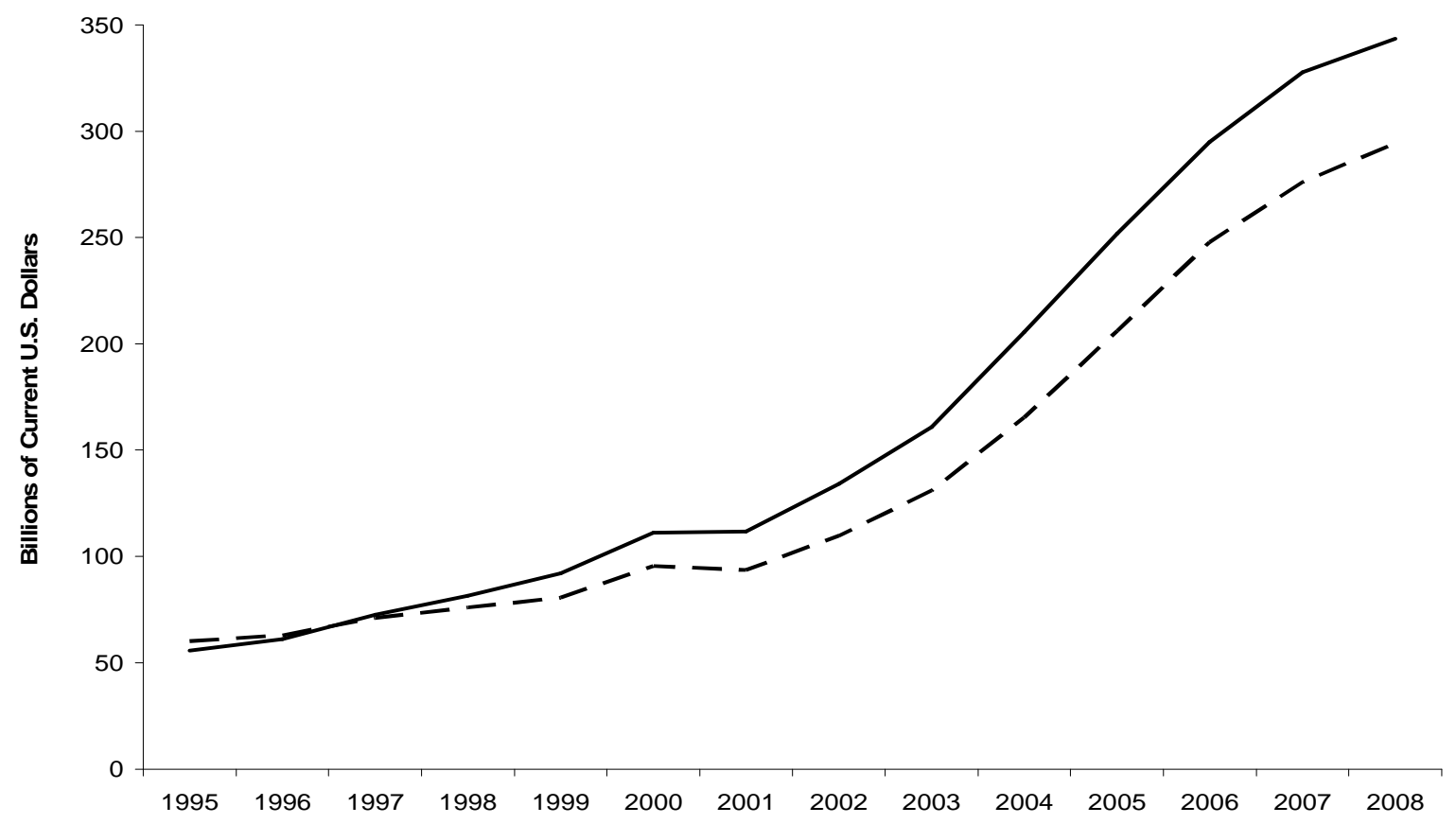

—US reported imports from China \& Hong Kong (fob) - - China \& Hong Kong reported exports to US (fob) Notes: Data are updated by authors based on Ferrantino and Wang (2008). The data are corrected by shipping margins and geography. 
Figure 2a. The discrepancy grows as Hong Kong's "middleman" role shrinks

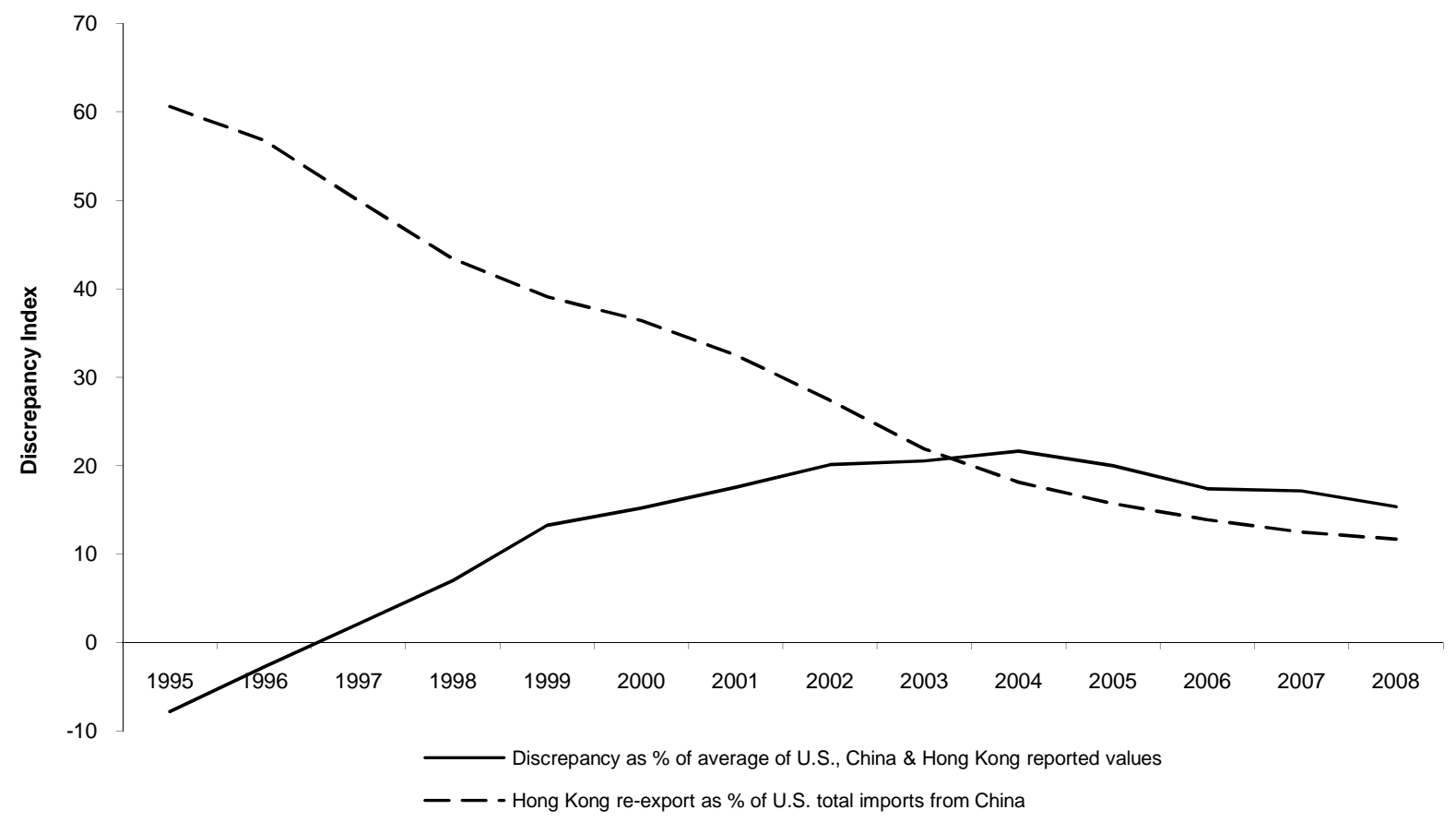

Notes: Data are updated by authors based on Ferrantino and Wang (2008). Discrepancy is measured by $(\mathrm{M}-\mathrm{X}) /[(\mathrm{M}+\mathrm{X}) / 2]$ which is approximately equivalent to $\mathrm{GAP}=\ln (\mathrm{M})-\ln (\mathrm{X})$.

Figure $2 b$ Statistical sources of China-U.S. eastbound trade data discrepancies

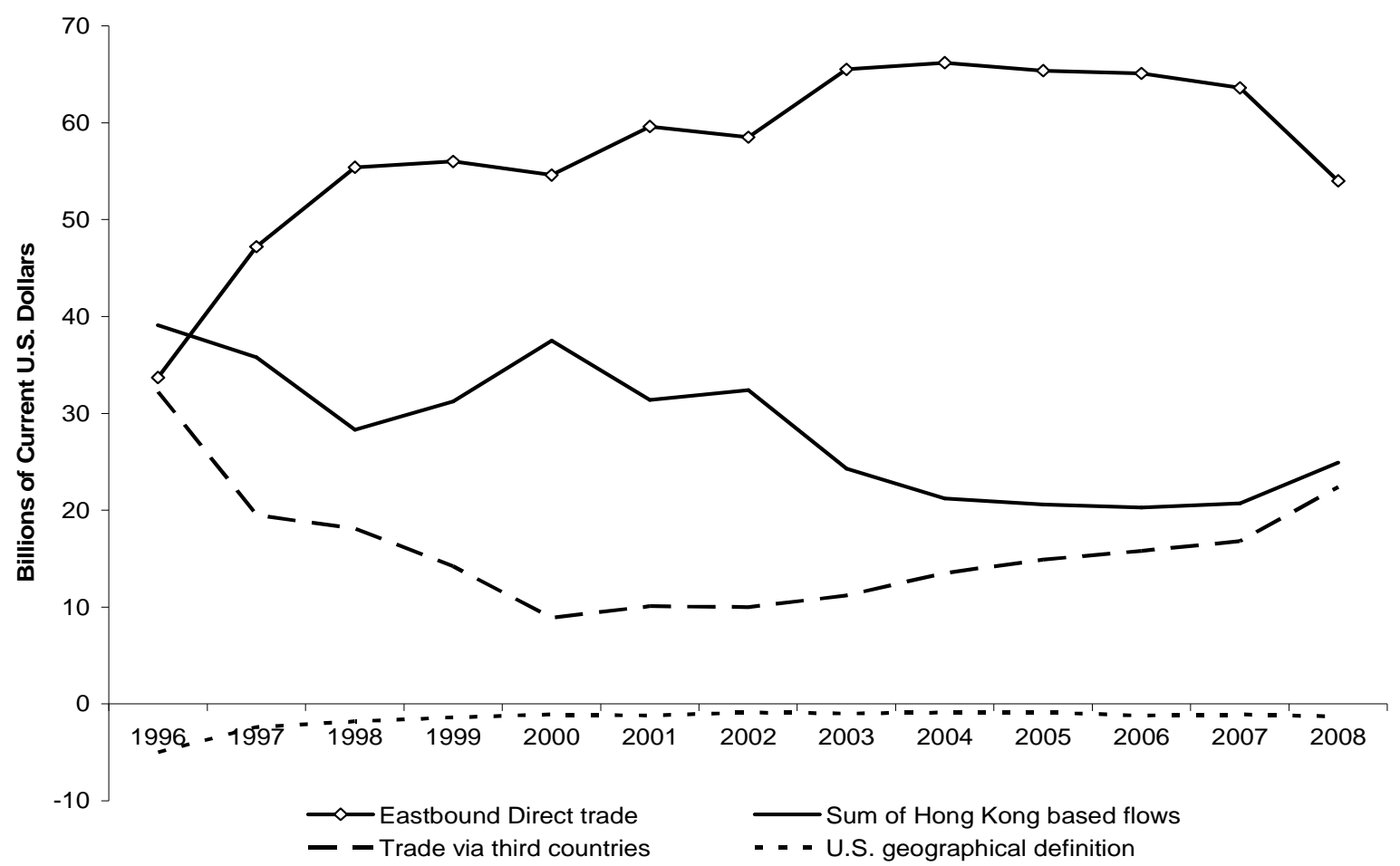

Notes: Data are updated by authors based on Ferrantino and Wang (2008). 
Figure 3: Direct trade gap and estimated net capital flight from China

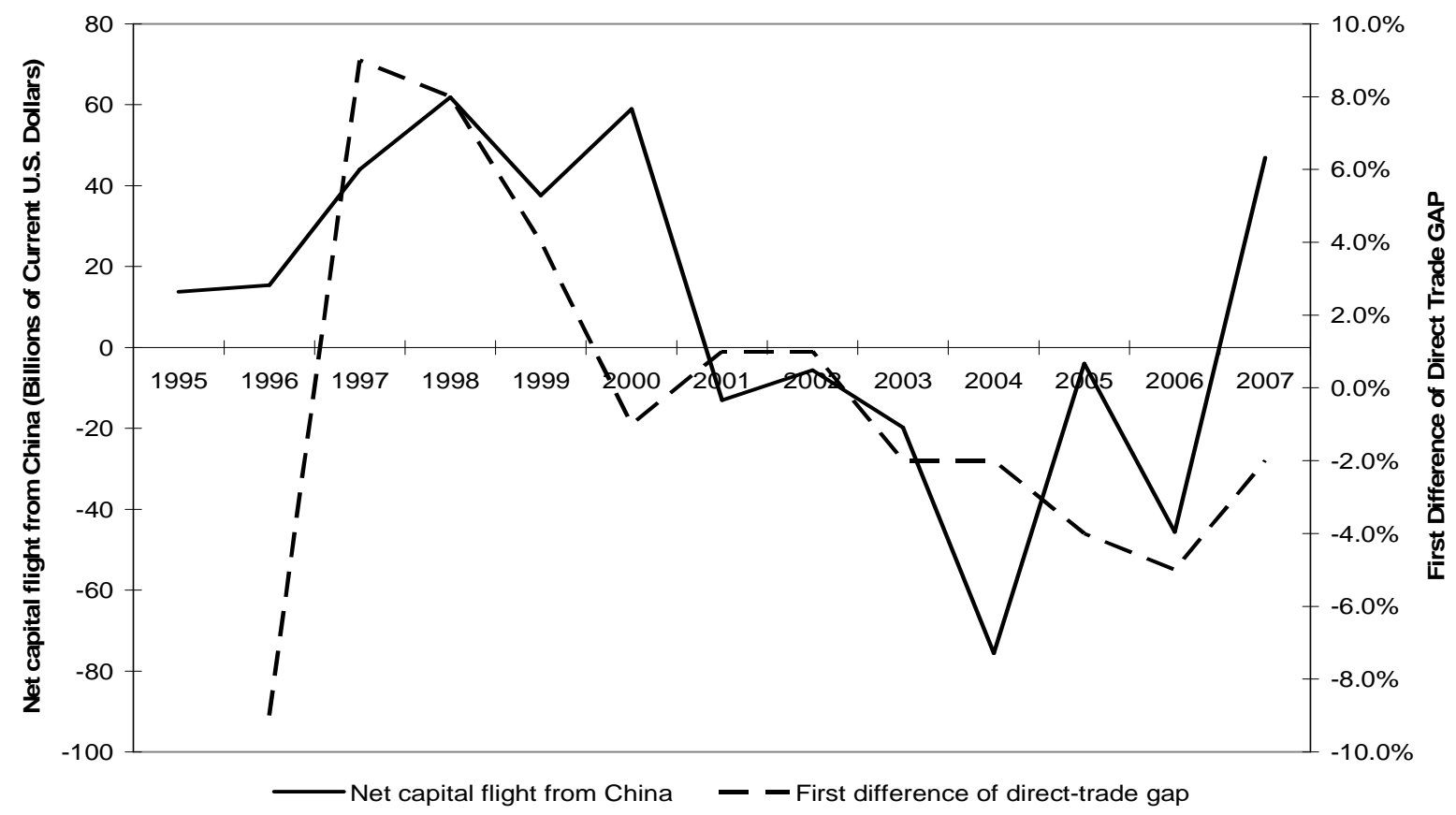

Notes: Data are updated by authors based on Ferrantino and Wang (2008). Net capital flight from China is based on the World Bank residual measure. The discrepancy is the first difference of the GAP reported on the second column of Table 1 .

Figure 4: Kernel density of GAP by sample year

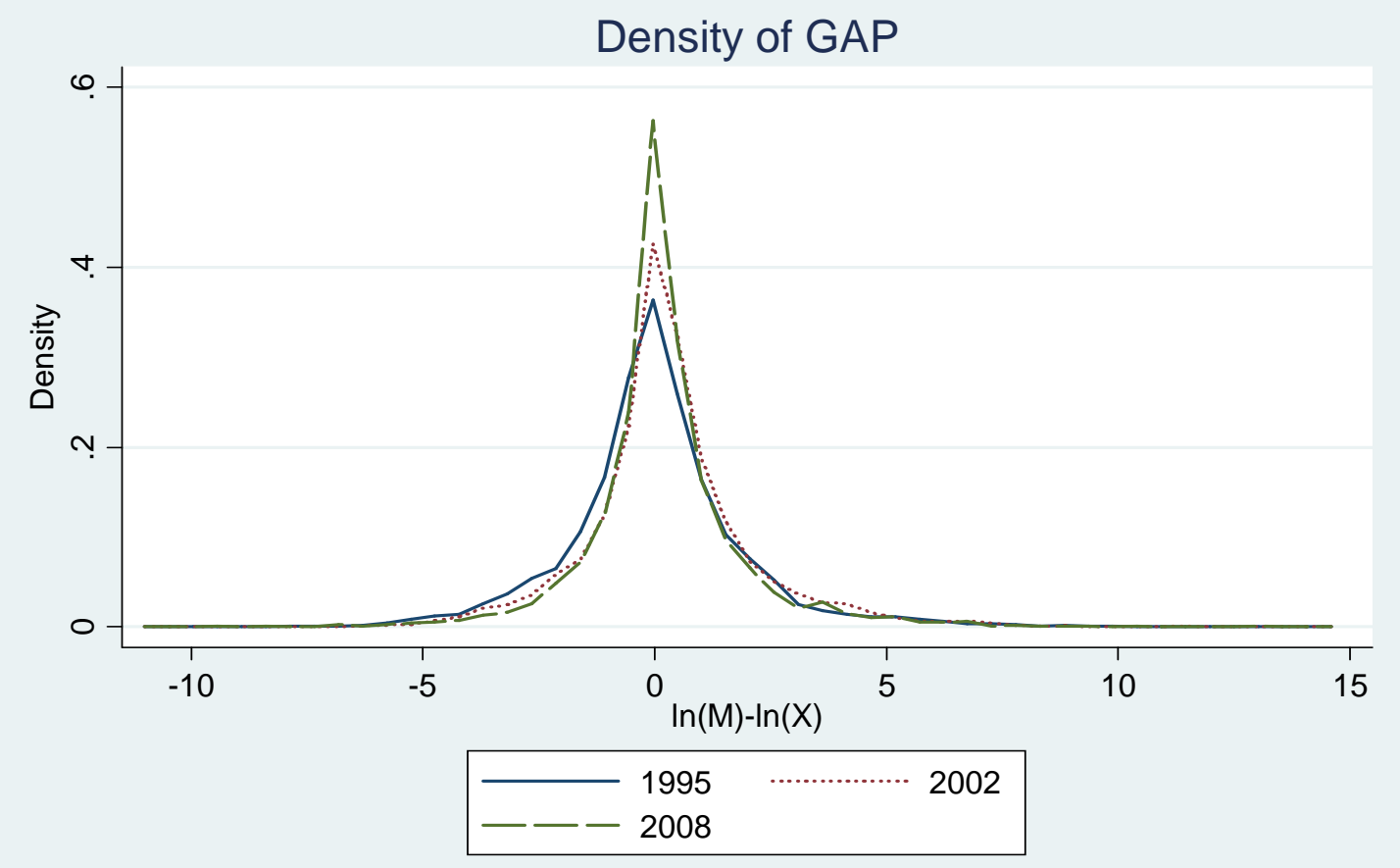


Figure 5: Quantile versus OLS estimation of VAT's coefficient, based on first differenced data

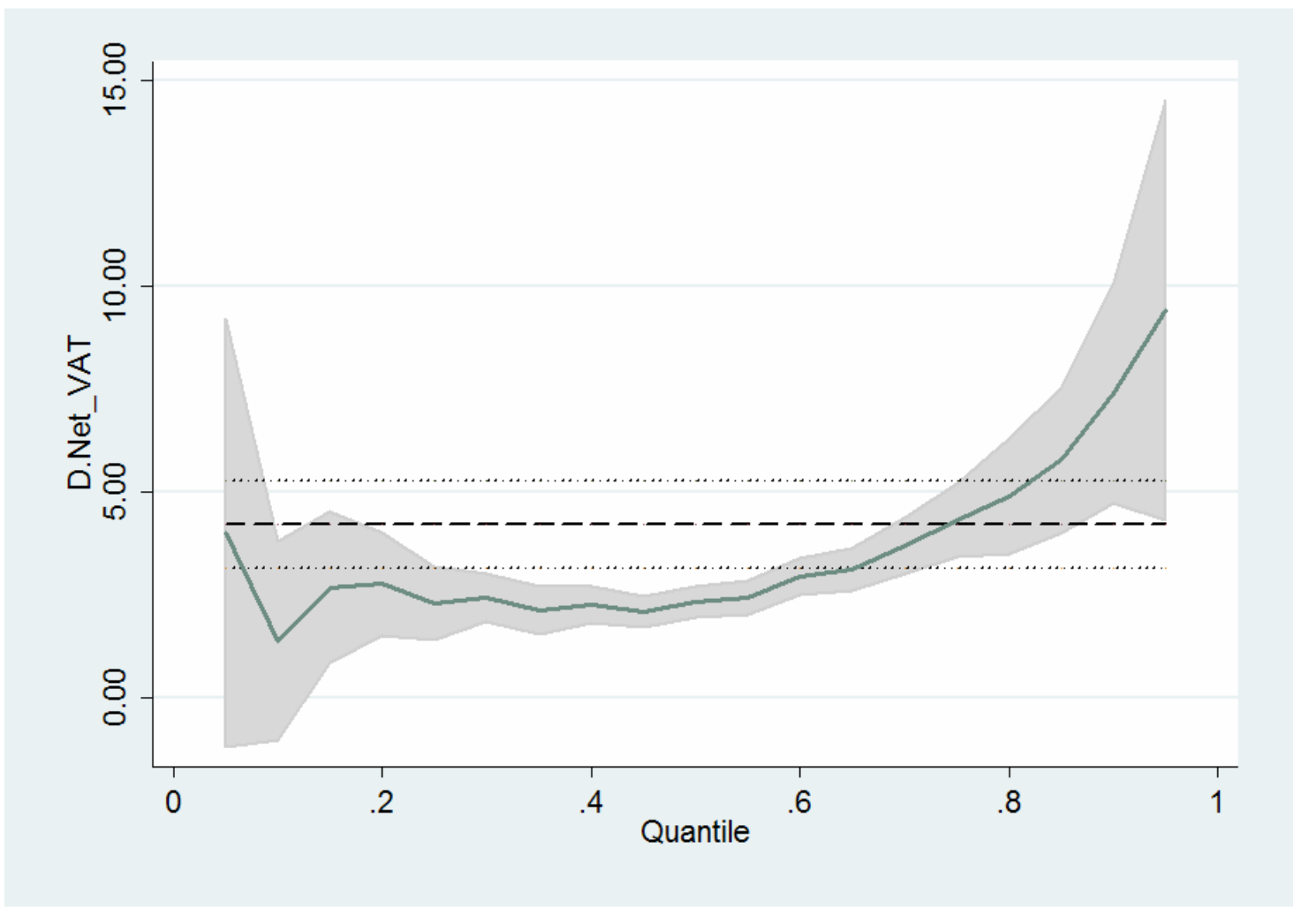

Notes:

1. The curved solid line represents the estimates from quantile regressions with the shaded area as the $95 \%$ confidence interval of the coefficient (quantile increment $=0.05$ );

2. The straight dashed line represents the estimate from OLS with the dotted line as the $95 \%$ confidence interval of the coefficient. 
Table 1: China-U.S. trade data Discrepancies, 1995-2008

\begin{tabular}{|c|c|c|c|c|c|c|c|c|}
\hline \multirow[b]{2}{*}{ Year } & \multirow{2}{*}{$\begin{array}{c}\text { Trade } \\
\text { weighted } \\
\text { GAP }\end{array}$} & \multicolumn{5}{|c|}{ Whole Sample by HS-6 } & \multirow{2}{*}{$\begin{array}{c}\text { Mean(GAP) } \\
\text { when GAP }>=0 \\
\text { [share of lines] }\end{array}$} & \multirow{2}{*}{$\begin{array}{c}\text { Mean(GAP) } \\
\text { when GAP }<0 \\
{[\text { share of lines] }}\end{array}$} \\
\hline & & $\begin{array}{l}\# \text { of } \\
\text { Obs. }\end{array}$ & Mean & $\begin{array}{l}\text { Std. } \\
\text { Dev. }\end{array}$ & Min & $\operatorname{Max}$ & & \\
\hline 1995 & 0.19 & 2427 & 0.00 & 1.92 & -10.89 & 10.13 & $1.38[47 \%]$ & $-1.24[53 \%]$ \\
\hline 1996 & 0.10 & 2544 & -0.06 & 1.81 & -7.47 & 11.77 & $1.21[48 \%]$ & $-1.25[52 \%]$ \\
\hline 1997 & 0.19 & 2777 & 0.05 & 1.90 & -8.56 & 13.42 & $1.30[52 \%]$ & $-1.29[48 \%]$ \\
\hline 1998 & 0.27 & 2917 & 0.09 & 1.90 & -8.86 & 10.76 & $1.30[53 \%]$ & $-1.27[47 \%]$ \\
\hline 1999 & 0.31 & 3056 & 0.16 & 2.01 & -8.71 & 11.64 & $1.37[54 \%]$ & $-1.26[46 \%]$ \\
\hline 2000 & 0.30 & 3202 & 0.21 & 1.95 & -6.89 & 12.79 & $1.36[56 \%]$ & $-1.24[44 \%]$ \\
\hline 2001 & 0.31 & 3270 & 0.30 & 1.89 & -7.95 & 12.04 & $1.36[57 \%]$ & $-1.12[43 \%]$ \\
\hline 2002 & 0.32 & 3480 & 0.30 & 1.84 & -7.82 & 13.04 & $1.32[58 \%]$ & $-1.12[42 \%]$ \\
\hline 2003 & 0.30 & 3578 & 0.32 & 1.83 & -8.94 & 14.48 & $1.31[59 \%]$ & $-1.09[41 \%]$ \\
\hline 2004 & 0.28 & 3724 & 0.36 & 1.84 & -7.43 & 12.63 & $1.35[59 \%]$ & $-1.05[41 \%]$ \\
\hline 2005 & 0.24 & 3856 & 0.29 & 1.83 & -8.75 & 11.87 & $1.26[58 \%]$ & $-1.06[42 \%]$ \\
\hline 2006 & 0.19 & 3996 & 0.29 & 1.85 & -8.10 & 13.47 & $1.30[57 \%]$ & $-1.05[43 \%]$ \\
\hline 2007 & 0.17 & 3887 & 0.27 & 1.76 & -7.86 & 14.30 & $1.18[58 \%]$ & $-1.00[42 \%]$ \\
\hline 2008 & 0.13 & 3808 & 0.22 & 1.72 & -9.46 & 13.06 & $1.17[55 \%]$ & $-0.96[45 \%]$ \\
\hline $\begin{array}{l}2002- \\
2008\end{array}$ & 0.21 & 22849 & 0.29 & 1.81 & -9.46 & 14.48 & $1.26[58 \%]$ & $-1.03[42 \%]$ \\
\hline
\end{tabular}

Notes:

1. Trade weighted GAP is the aggregate GAP by year (i.e., log difference in total $\mathrm{M}$ and $\mathrm{X}$ for each year);

2. Only 65 products have zero discrepancies over 1995-2008 and they are included in the "GAP>=0" category;

3. Share of lines refers to the share of product lines at HS-6 level in the sample.

Table 2: Descriptive statistics of explanatory variables, simple average, 2002-2008

\begin{tabular}{|c|c|c|c|c|c|c|c|}
\hline \multirow[b]{2}{*}{ Explanatory Variables } & \multirow{2}{*}{$\begin{array}{c}\text { Trade } \\
\text { weighted } \\
\text { average }\end{array}$} & \multicolumn{4}{|c|}{ At HS-6 product level } & \multirow{2}{*}{$\begin{array}{l}\text { Mean(GAP) of } \\
\text { high X products } \\
\text { [share of lines] }\end{array}$} & \multirow{2}{*}{$\begin{array}{l}\text { Mean(GAP) of } \\
\text { low X products } \\
\text { [share of lines] }\end{array}$} \\
\hline & & Mean & $\begin{array}{l}\text { Std. } \\
\text { Dev. }\end{array}$ & Min & Max & & \\
\hline China net VAT & 0.04 & 0.05 & 0.04 & 0 & 0.17 & $0.50[27 \%]$ & $0.18[73 \%]$ \\
\hline U.S. import tariffs & 0.03 & 0.04 & 0.05 & 0 & 0.80 & $0.03[36 \%]$ & $0.41[64 \%]$ \\
\hline Related party share & 0.24 & 0.11 & 0.19 & 0 & 1 & $0.27[26 \%]$ & $0.27[74 \%]$ \\
\hline Share of processing exports & 0.60 & 0.24 & 0.32 & 0 & 1 & $0.09[35 \%]$ & $0.36[65 \%]$ \\
\hline Share of FIE firms exports & 0.64 & 0.37 & 0.34 & 0 & 1 & $0.17[45 \%]$ & $0.35[55 \%]$ \\
\hline
\end{tabular}

\section{Notes:}

1. This table is based on the sample used in the first regression in Table 3 (\# of Obs. = 26033);

2. The weight for tariff and related party share is U.S. recorded import (M);

3. The weight for VAT and shares of processing and FIE firm exports is China recorded export (X);

4. "High $X$ products" are products with $X>=\operatorname{mean}(\mathrm{X})$ in a year, where $\mathrm{X}$ is an explanatory variable;

5. "Low X products" are products with $X<$ mean $(X)$ in a year, where $X$ is an explanatory variable;

6. Share of lines refers to the share of product lines at HS-6 level in the sample. 
Table 3: Baseline regression results

\begin{tabular}{|c|c|c|c|c|}
\hline & $(1)$ & (2) & (3) & (4) \\
\hline & Pool data & $\mathrm{FE}$ & Pool data & FE \\
\hline \multirow[t]{2}{*}{ Net VAT rate } & $4.949 * * *$ & $3.663 * * *$ & $5.864 * * *$ & $4.124 * * *$ \\
\hline & $(0.573)$ & $(0.470)$ & $(0.747)$ & $(0.585)$ \\
\hline \multirow[t]{2}{*}{ U.S. import Tariffs } & $-3.304 * * *$ & $-1.772 *$ & $-2.965 * * *$ & -1.339 \\
\hline & $(0.413)$ & $(1.004)$ & $(0.441)$ & $(1.014)$ \\
\hline \multirow[t]{2}{*}{ Related party share } & $0.248 * *$ & $0.171 *$ & $0.383 * * *$ & $0.343 * * *$ \\
\hline & $(0.099)$ & $(0.089)$ & $(0.119)$ & $(0.110)$ \\
\hline \multirow[t]{2}{*}{ Share of processing exports } & $-0.386^{* * *}$ & $-0.885 * * *$ & $-0.219 * *$ & $-0.732 * * *$ \\
\hline & $(0.066)$ & $(0.068)$ & $(0.093)$ & $(0.084)$ \\
\hline \multirow[t]{2}{*}{ Share of FIE exports } & $-0.206^{* * *}$ & $-0.303 * * *$ & $-0.200 * *$ & $-0.314 * * *$ \\
\hline & $(0.063)$ & $(0.061)$ & $(0.092)$ & $(0.079)$ \\
\hline \multirow[t]{2}{*}{$\mathrm{VAT}^{*}$ Share of processing exports } & & & $-3.869 * * *$ & $-3.141 * *$ \\
\hline & & & $(1.370)$ & $(1.238)$ \\
\hline \multirow{2}{*}{ VAT*Share of FIE exports } & & & -0.124 & 0.206 \\
\hline & & & $(1.371)$ & $(1.192)$ \\
\hline \multirow[t]{2}{*}{ Tariffs*Related party share } & & & $-6.169 * *$ & $-5.950 * *$ \\
\hline & & & $(2.672)$ & $(2.349)$ \\
\hline \multirow[t]{2}{*}{ Year Dummy 2003} & 0.013 & 0.022 & 0.015 & 0.023 \\
\hline & $(0.029)$ & $(0.030)$ & $(0.029)$ & $(0.030)$ \\
\hline \multirow[t]{2}{*}{ Year Dummy 2004} & $-0.076 * *$ & $-0.054 *$ & $-0.072 * *$ & -0.047 \\
\hline & $(0.035)$ & $(0.030)$ & $(0.035)$ & $(0.031)$ \\
\hline \multirow[t]{2}{*}{ Year Dummy 2005} & $-0.139 * * *$ & $-0.094 * * *$ & $-0.136^{* * *}$ & $-0.087 * * *$ \\
\hline & $(0.036)$ & $(0.030)$ & $(0.036)$ & $(0.030)$ \\
\hline \multirow[t]{2}{*}{ Year Dummy 2006} & $-0.164 * * *$ & $-0.126 * * *$ & $-0.161 * * *$ & $-0.119 * * *$ \\
\hline & $(0.038)$ & $(0.031)$ & $(0.038)$ & $(0.031)$ \\
\hline \multirow[t]{2}{*}{ Year Dummy 2007} & $-0.282 * * *$ & $-0.224 * * *$ & $-0.282 * * *$ & $-0.216^{* * * *}$ \\
\hline & $(0.044)$ & $(0.036)$ & $(0.044)$ & $(0.036)$ \\
\hline \multirow[t]{2}{*}{ Year Dummy 2008} & $-0.384 * * *$ & $-0.299 * * *$ & $-0.383 * * *$ & $-0.289 * * *$ \\
\hline & $(0.049)$ & $(0.039)$ & $(0.049)$ & $(0.039)$ \\
\hline HS-6 product fixed effects (FE) & & Yes & & Yes \\
\hline Rho & & 0.687 & & 0.687 \\
\hline Observations & 26033 & 26033 & 26033 & 26033 \\
\hline R-squared & 0.027 & & 0.029 & \\
\hline
\end{tabular}

Notes:

1. Robust standard errors in parentheses, clustered by HS 6-digit products in pooled data regression;

2. * significant at 10 percent; $* *$ significant at 5percent; $* * *$ significant at 1 percent. 
Table 4: Regressions without outliers and first difference regression

\begin{tabular}{|c|c|c|c|}
\hline & \multicolumn{2}{|c|}{$\begin{array}{l}\text { Without } 5 \% \text { outliers of } \\
\text { GAP on both sides }\end{array}$} & \multirow{2}{*}{$\begin{array}{c}\begin{array}{c}\text { First } \\
\text { Difference }\end{array} \\
(3)\end{array}$} \\
\hline & (1) & (2) & \\
\hline & Pooled Data & Fixed Effects & Pooled Data \\
\hline \multirow[t]{2}{*}{ Net VAT rate } & $2.515 * * *$ & $2.791 * * *$ & $4.227 * * *$ \\
\hline & $(0.348)$ & $(0.309)$ & $(0.624)$ \\
\hline \multirow[t]{2}{*}{ U.S. import Tariffs } & $-1.295 * * *$ & -1.045 & $-2.665^{*}$ \\
\hline & $(0.252)$ & $(0.778)$ & $(1.540)$ \\
\hline \multirow[t]{2}{*}{ Related party share } & $0.103^{*}$ & $0.233 * * *$ & $0.181 *$ \\
\hline & $(0.058)$ & $(0.060)$ & $(0.107)$ \\
\hline \multirow[t]{2}{*}{ Share of processing exports } & -0.005 & $-0.452 * * *$ & $-0.804 * * *$ \\
\hline & $(0.043)$ & $(0.046)$ & $(0.093)$ \\
\hline \multirow[t]{2}{*}{ Share of FIE exports } & $-0.117 * * *$ & $-0.196 * * *$ & $-0.326 * * *$ \\
\hline & $(0.041)$ & $(0.040)$ & $(0.083)$ \\
\hline Year dummies & Yes & Yes & Yes \\
\hline HS-6 product fixed effects $(\mathrm{FE})$ & & Yes & \\
\hline Observations & 23686 & 23686 & 20760 \\
\hline R-squared & 0.011 & & 0.023 \\
\hline
\end{tabular}

Notes:

1. Robust standard errors in parentheses, clustered by HS 6-digit products in pooled data regression;

2. * significant at 10 percent; ** significant at 5 percent; *** significant at 1 percent;

3. The outliers of GAP is based on the whole sample, not limited to the sample covered by regressions ( $\mathrm{p} 5=-2.658$ and $\mathrm{p} 95=3.367)$.

Table 5: Simultaneous quantile regressions, based on the first differenced data

\begin{tabular}{llllll}
\hline & $(1)$ & $(2)$ & $(3)$ & $(4)$ & $(5)$ \\
\hline \multirow{3}{*}{ Net VAT rate } & $\mathrm{q} 10$ & $\mathrm{q} 25$ & $\mathrm{q} 50$ & $\mathrm{q} 75$ & $\mathrm{q} 90$ \\
& 1.398 & $2.306^{* * *}$ & $2.335^{* * *}$ & $4.331 * * *$ & $7.416^{* * *}$ \\
U.S. import Tariffs & $(1.402)$ & $(0.513)$ & $(0.269)$ & $(0.626)$ & $(1.249)$ \\
& $-3.658^{*}$ & $-1.685^{* *}$ & $-1.309^{* *}$ & $-1.512^{*}$ & -1.567 \\
Related party share & $(2.151)$ & $(0.809)$ & $(0.587)$ & $(0.873)$ & $(1.476)$ \\
& 0.213 & $0.169 * *$ & $0.145^{* * *}$ & $0.237 * * *$ & $0.378^{* * *}$ \\
Share of processing exports & $(0.147)$ & $(0.072)$ & $(0.049)$ & $(0.077)$ & $(0.119)$ \\
& $-0.861 * * *$ & $-0.566^{* * *}$ & $-0.415 * * *$ & $-0.433^{* * *}$ & $-0.631 * * *$ \\
Share of FIE exports & $(0.100)$ & $(0.081)$ & $(0.057)$ & $(0.078)$ & $(0.137)$ \\
& $-0.387 * * *$ & $-0.298^{* * *}$ & $-0.263 * * *$ & $-0.321 * * *$ & $-0.364 * * *$ \\
Year dummies & $(0.091)$ & $(0.065)$ & $(0.047)$ & $(0.064)$ & $(0.100)$ \\
Observations & Yes & Yes & Yes & Yes & Yes \\
\hline
\end{tabular}

Notes:

1. Bootstrapped standard errors are in the parentheses (based on 100 replications);

2. * significant at 10percent; ** significant at 5percent; *** significant at 1 percent. 